\title{
An Evaluation of the Chalcogen Atom Effect on the Mesomorphic and Electronic Properties in a New Homologous Series of Chalcogeno Esters
}

\author{
Daniel S. Rampon, ${ }^{a}$ Fabiano S. Rodembusch, ${ }^{a}$ Paulo F. B. Gonçalves, ${ }^{b}$ \\ Rogério V. Lourega, ${ }^{c}$ Aloir A. Merlo ${ }^{*, a}$ and Paulo H. Schneider $*, a$ \\ ${ }^{a}$ Instituto de Química, Universidade Federal do Rio Grande do Sul, CP 15003, \\ 91501-970 Porto Alegre-RS, Brazil \\ ${ }^{b}$ Instituto de Química, Centro Universitário La Salle. Av. Victor Barreto, 2288. Centro, \\ 92010-000 Canoas-RS, Brazil \\ 'Faculdade de Química, Pontifícia Universidade Católica do Rio Grande do Sul, Av. Ipiranga, 6681, \\ Partenon, 90619-900 Porto Alegre-RS, Brazil
}

\begin{abstract}
Uma série de calcogeno ésteres, 1a, $\mathbf{6} \mathbf{a}$ e $\mathbf{6 b}$ foi obtida em uma rota sintética conveniente. A análise de microscopia óptica de luz polarizada (POM) e calorimetria diferencial de varredura (DSC) mostrou que estes calcogeno ésteres apresentam uma ampla faixa de mesofase nemática. Além disso, espectros de absorção na região do UV-Vis em solução (ca.10-5 mol L-1) também foram obtidos de maneira a se obter a diferença de energia entre os orbitais moleculares HOMO-LUMO, para posterior comparação com os resultados teóricos. Os valores calculados para o gap de HOMO-LUMO estão de acordo com os valores experimentais obtidos, onde a eletronegatividade do heteroátomo $(\mathrm{O}, \mathrm{S}$ e Se) deve ser o principal fator para a localização do máximo de absorção. Um estudo teórico foi realizado utilizando cálculos de DFT/B3LYP com método híbrido de Becke aplicando uma correlação funcional de Lee-Yang-Parr (B3LYP) com a base DGDZVP a fim de avaliar algumas propriedades físico-químicas relacionadas com o mesomorfismo e as propriedades eletrônicas espectrais. Através da síntese destes compostos, a influência do átomo de calcogênio nas propriedades fotofísicas e mesomórficas pôde ser avaliada de uma forma mais precisa.
\end{abstract}

A series of chalcogeno esters 1a, $\mathbf{6 a}$ and $\mathbf{6 b}$ have been synthesized in a straightforward manner. Polarized-light optical microscopy (POM) and differential scanning calorimetry (DSC) showed that these chalcogeno esters displayed a wide nematic range of mesophase. In addition, UV-Vis in solution $\left(c a .10^{-5} \mathrm{~mol} \mathrm{~L}^{-1}\right)$ was applied in order to obtain the HOMO-LUMO gap for further comparison with the theoretical results. The calculated values to the HOMO-LUMO gap are in excellent agreement with the experimental results, where the electronegativity of the heteroatom $(\mathrm{O}, \mathrm{S}$ and $\mathrm{Se}$ ) seems to play a fundamental role in the absorption maxima location. A theoretical study was performed using a DFT/B3LYP calculations with Becke's three-parameter hybrid method applying the Lee-Yang-Parr functional correlation (B3LYP) with DGDZVP basis set in order to evaluate some physical chemistry data related with mesomorphic and spectral eletronic properties. By synthesizing these compounds we were able to get a more precise description about the influence of the chalcogen atom on the mesomorphic and photophysical properties.

Keywords: chalcogeno ester, liquid crystals, electronic properties, photophysical behavior

\section{Introduction}

Chalcogenide compounds have found such wide utility because their effects on an extraordinary number of very

*e-mail: paulos@iq.ufrgs.br different reactions. ${ }^{1}$ In addition, they have become attractive synthetic targets because of their chemo and regioselective reactions, ${ }^{2}$ tolerating a large variety of functional groups, thus avoiding protection group chemistry. More recently, chalcogen containing compounds have been used as chiral catalysts or as chiral ligands in various stereoselective reactions. ${ }^{3}$ 
The biological and medicinal properties of selenium and organoselenium compounds are increasingly appreciated, mainly due to their antioxidant, antitumor, antimicrobial and antiviral properties. ${ }^{4}$ Besides, the synthesis of peptides containing selenocysteine is rapidly gaining interest with the discovery of an increasing number of proteins containing this aminoacid. ${ }^{5}$

Chalcogeno esters (thiol, selenol and tellurol esters) are useful synthetic intermediates that have been employed, for example, as acylating reagents, building blocks for heterocyclic compounds, precursors of acyl radicals and anions, as well asymmetric aldol reactions. However, rare are the examples where these compounds are reported as liquid-crystalline materials despite its promising photophysical properties for optical device applications such as emissive LC (liquid crystals) displays, polarized organic lasers, anisotropic OLEDs and organic field-effect transistors (OFETs). ${ }^{6}$

In the course of our work in the field of liquid-crystalline materials, we have reported selenoesters 1 (Figure 1), which exhibited liquid crystalline properties over a large range of temperature. ${ }^{7}$ In addition, these selenoesters-LC are fluorescent in the blue region presenting a Stokes shift higher than $39 \mathrm{~nm}$.

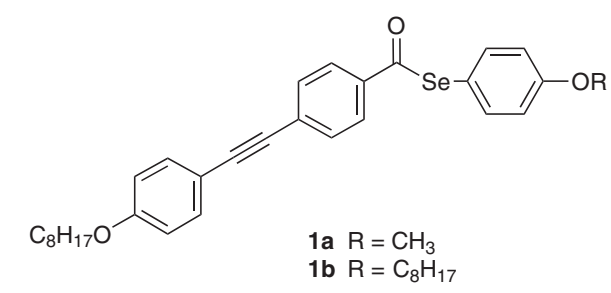

Figure 1. Selenoesters-LC 1a and 1b.

The general structure of selenoesters $\mathbf{1}$ is very attractive for several reasons. It can be synthesized in a straightforward manner which allows us to explore the effects of the chalcogen atom on the stability and packing order in the mesophase as well on their photophysical behavior. Most important, chalcogeno esters with high structural diversity can be readily generated, with is important for the systematic evaluation of the real influence of the chalcogen atom on the mesomorphic behavior. Earlier studies, shown for example that different chalcogen atoms in a series of compounds can induce changes in their photophysical properties. ${ }^{8}$

In connection with our current interests in the study of the mesomorphic properties of some chalcogencontaining compounds, the objectives of this work were to investigate the photophysical and LC properties of the chalcogeno esters, focused on the chalcogen atom. In additions perform some theoretical studies using DFT/ B3LYP calculations with DGDZVP basis set.

\section{Experimental}

\section{General}

4-Bromophenol, 1-bromoalkanes, 2-methyl-3-butyn2-ol (mebynol), $\mathrm{KOH}$, triphenylphosphine $\left(\mathrm{PPh}_{3}\right)$, tributylphosphine $\left(\mathrm{PBu}_{3}\right)$, dimethylformamide (DMF), CuI, $N, N$ '-dicyclohexylcarbodiimide (DCC), 4-dimethylaminopyridine (DMAP), benzene, ethanol and 4-bromobenzoic acid were used without further purification from Aldrich. Triethylamine was distilled over $\mathrm{KOH}$ and isopropyl alcohol and dichloromethane distilled over $\mathrm{CaH}_{2}$ under argon immediately prior to use. All other commercial solvents and reagents were used without further purification. The reactions were accompanied by analytical thin-layer chromatography (TLC), conducted on Merck aluminum plates with $0.2 \mathrm{~mm}$ of Silica Gel $60 \mathrm{~F}_{254}$. The melting points and mesophase transition temperatures and textures of the samples were measured on a Mettler Toledo FP82HT Hot Stage FP90 Central Processor and DSC Q2000 Series TA Instruments. Nuclear magnetic resonance spectra were obtained on a Varian $300 \mathrm{MHz}$ instrument. Chemical shift are given in parts per million (d) and are referenced from tetramethylsilane (TMS). ATR/FTIR spectra were recorded on a Varian FT-IR-640 spectrometer. CHN analyses were performed on a Perkin-Elmer 2400 CHN Elemental Analyzer. High resolution mass spectra were recorded on a Micromass Q-TOFmicro instrument. Spectroscopic grade dichloromethane was used to UV-Vis absorption spectroscopy measurements. UV-Vis absorption spectra were recorded in a Shimadzu UV-2450PC spectrometer. All experiments were performed at room temperature in a concentration of $10^{-5} \mathrm{~mol} \mathrm{~L}^{-1}$.

\section{Synthesis}

\section{1-Ethynyl-4-(octyloxy)benzene (2)}

Alkylation reaction: ${ }^{9}$ 4-Bromophenol (26 g, $150 \mathrm{mmol})$ and potassium hydroxide $(10 \mathrm{~g}, 178 \mathrm{mmol})$ were added to benzene and DMF $(1: 1,200 \mathrm{~mL})$ and heated at $50{ }^{\circ} \mathrm{C}$ for $15 \mathrm{~min}$. Then, $n$-octylbromide ( $31 \mathrm{~mL}, 178 \mathrm{mmol}$ ) was added dropwise and the mixture heated $\left(90^{\circ} \mathrm{C}\right)$ under reflux for $6 \mathrm{~h}$. The solid formed was filtered off and the filtrate concentrated. The residue was dissolved in diethyl ether $(200 \mathrm{~mL})$, washed with $10 \%$ sodium bicarbonate solution $(2 \times 100 \mathrm{~mL})$, and water $(100 \mathrm{~mL})$, then dried over anhydrous sodium sulfate. The solvent was removed by evaporation and the product purified by distillation under reduced pressure. The compound was obtained as pale yellow viscous liquid. Yield: $34.6 \mathrm{~g}, 81 \%$; bp $117{ }^{\circ} \mathrm{C}(1 \mathrm{mmHg}) .{ }^{1} \mathrm{H}$ NMR 
$\left(\mathrm{CDCl}_{3}\right): \delta 0.88\left(\mathrm{t}, 3 \mathrm{H}, \mathrm{CH}_{3}\right), 1.28\left(\mathrm{~m}, 10 \mathrm{H},\left(\mathrm{CH}_{2}\right)_{5}\right), 1.72$ $\left(\mathrm{m}, 2 \mathrm{H}, \mathrm{CH}_{2} \mathrm{CH}_{2} \mathrm{O}\right), 3.83$ (t, J $\left.6.5 \mathrm{~Hz}, 2 \mathrm{H}, \mathrm{CH}_{2} \mathrm{O}\right), 6.71$ (d, $J 8.9 \mathrm{~Hz}, 2 \mathrm{H}, \mathrm{Ar}), 7.3(\mathrm{~d}, J 8.9 \mathrm{~Hz}, 2 \mathrm{H}, \mathrm{Ar}) ;{ }^{13} \mathrm{C} \mathrm{NMR}$ $\left(\mathrm{CDCl}_{3}\right): \delta 14.0,22.6,25.9,29.1,29.2,29.3,31.7,68.1$, 112.4, 116.1, 117.2, 132, 132.2, 158.1.

Sonogashira coupling reaction: ${ }^{9}$ A test tube was charged with $\mathrm{Et}_{3} \mathrm{~N}$ (100 mL), 2-methyl-3-butyn-2-ol (7 mL, $70 \mathrm{mmol}$ ) and 1-bromo-4-(octyloxy)benzene (7) (9 g, $32 \mathrm{mmol})$ under argon. To the solution were added $\mathrm{CuI}(216 \mathrm{mg}), \mathrm{PPh}_{3}(123 \mathrm{mg})$ and $\mathrm{PdCl}_{2}\left(\mathrm{PPh}_{3}\right)_{2}(69 \mathrm{mg})$. The mixture was heated for $24 \mathrm{~h}$ at $90{ }^{\circ} \mathrm{C}$. After cooling, the solid was filtered and washed with $\mathrm{CH}_{2} \mathrm{Cl}_{2}(100 \mathrm{~mL})$. The filtered mixture was evaporated, and the resulting dark yellow oil was dissolved in $\mathrm{CH}_{2} \mathrm{Cl}_{2}(200 \mathrm{~mL})$ and washed with water $(3 \times 80 \mathrm{~mL})$, cold $5 \mathrm{~mol} \mathrm{~L}^{-1}$ hydrochloric acid $(80 \mathrm{~mL})$ and water $(80 \mathrm{~mL})$. The organic layer was dried over anhydrous sodium sulfate. The solvent was evaporated and the remaining solid was purified by chromatography. A yellow solid was obtained in $42 \%$ yield. Yield: $3.8 \mathrm{~g}, 42 \%$; $\mathrm{mp} 60.2{ }^{\circ} \mathrm{C} .{ }^{1} \mathrm{H}$ NMR $\left(\mathrm{CDCl}_{3}\right)$ : $\delta 0.89\left(\mathrm{t}, 3 \mathrm{H}, \mathrm{CH}_{3}\right), 1.3\left(\mathrm{~m}, 10 \mathrm{H},\left(\mathrm{CH}_{2}\right)_{5}\right), 1.6(\mathrm{~s}, 6 \mathrm{H}$, $\left.\mathrm{CH}_{3}\right), 1.8\left(\mathrm{~m}, 2 \mathrm{H}, \mathrm{CH}_{2} \mathrm{CH}_{2} \mathrm{O}\right), 2.2(\mathrm{~s}, 1 \mathrm{H}, \mathrm{OH}), 3.9(\mathrm{t}$, $\left.J 6.6 \mathrm{~Hz}, 2 \mathrm{H}, \mathrm{CH}_{2} \mathrm{O}\right), 6.8(\mathrm{~d}, J 8.8 \mathrm{~Hz}, 2 \mathrm{H}, \mathrm{Ar}), 7.3(\mathrm{~d}$, $J 8.8 \mathrm{~Hz}, 2 \mathrm{H}, \mathrm{Ar}) .{ }^{13} \mathrm{C} \mathrm{NMR}\left(\mathrm{CDCl}_{3}\right): \delta 14.0,22.6,25.9$, 29.1, 29.2, 29.3, 31.5, 31.8, 65.7, 68.0, 76.6, 77.0, 77.4, 82.1, 92.2, 114.4, 114.5, 133.0, 159.1.

\section{4'-[4-(Octyloxyphenyl)ethynyl]benzoic acid (4)}

Deprotection and coupling reaction: ${ }^{9}$ Potassium hydroxide $(0.5 \mathrm{~g}, 9 \mathrm{mmol})$ and isopropyl alcohol $(40 \mathrm{~mL})$ were added to a round bottomed flask and heated at $50{ }^{\circ} \mathrm{C}$ for $15 \mathrm{~min}$. Then, a solution of 4'-(4-octyloxyphenyl)2-methylbut-3-yn-2-ol (8) (0.9 g, $3 \mathrm{mmol})$ in isopropyl alcohol $(10 \mathrm{~mL})$ was added. The mixture was heated under reflux for $2 \mathrm{~h}$. The solvent was evaporated, the residue dissolved in $\mathrm{CH}_{2} \mathrm{Cl}_{2}(50 \mathrm{~mL})$, and washed with water $(3 \times 30 \mathrm{~mL})$. The organic layer was dried over anhydrous sodium sulfate. The solvent was evaporated and a yellow oil was obtained in 99\% yield. This oil was used to another Sonogashira coupling with methyl 4-bromobenzoate (3). After cooling of reaction test tube, the solid was filtered and washed with $\mathrm{CH}_{2} \mathrm{Cl}_{2}(100 \mathrm{~mL})$. The filtered mixture was evaporated, and the resulting dark yellow oil was dissolved in $\mathrm{CH}_{2} \mathrm{Cl}_{2}(200 \mathrm{~mL})$ and washed with water $(3 \times 80 \mathrm{~mL})$, cold $5 \mathrm{~mol} \mathrm{~L}^{-1}$ hydrochloric acid $(80 \mathrm{~mL})$ and water $(80 \mathrm{~mL})$. The organic layer was dried over anhydrous sodium sulfate. The solvent was evaporated and the remaining solid was purified by chromatography and recrystallization from hexane. Yield: $1.79 \mathrm{~g}, 48 \%$; mp $112.6^{\circ} \mathrm{C} .{ }^{1} \mathrm{H}$ NMR $\left(\mathrm{CDCl}_{3}\right): \delta 0.89\left(\mathrm{t}, 3 \mathrm{H}, \mathrm{CH}_{3}\right), 1.3\left(\mathrm{~m}, 10 \mathrm{H},\left(\mathrm{CH}_{2}\right)_{5}\right)$, $1.8\left(\mathrm{~m}, 2 \mathrm{H}, \mathrm{CH}_{2} \mathrm{CH}_{2} \mathrm{O}\right), 3.92\left(\mathrm{~s}, 3 \mathrm{H}, \mathrm{CH}_{3} \mathrm{O}\right), 3.97$ (t, $\left.J 6.6 \mathrm{~Hz}, 2 \mathrm{H}, \mathrm{CH}_{2} \mathrm{O}\right), 6.9$ (d, J $\left.8.8 \mathrm{~Hz}, 2 \mathrm{H}, \mathrm{Ar}\right), 7.4$ (d, J $8.8 \mathrm{~Hz} \mathrm{~d}, 2 \mathrm{H}, \mathrm{Ar}), 7.6(\mathrm{~d}, J 8.1 \mathrm{~Hz}, 2 \mathrm{H}, \mathrm{Ar}), 8.0$ (d, $J 8.1 \mathrm{~Hz}, 2 \mathrm{H}, \mathrm{Ar}) .{ }^{13} \mathrm{C} \mathrm{NMR}\left(\mathrm{CDCl}_{3}\right): \delta 14.1,22.7$, 26.0, 29.1, 29.2, 29.3, 31.8, 52.2, 68.1, 77.2, 87.4, 92.7, $114.4,114.6,128.5,129.0,129.5,131.3,133.2,159.6$, 166.6 .

Hydrolysis reaction: ${ }^{10}$ Methyl-4'-(4-octyloxyphenyl) ethynyl benzoate (9) $(0.8 \mathrm{~g}, 2.3 \mathrm{mmol})$ was dissolved in THF $(30 \mathrm{~mL})$ and $1 \mathrm{~mol} \mathrm{~L}^{-1}$ aqueous $\mathrm{KOH}(12 \mathrm{~mL})$ was added. After heating the reaction mixture at $60{ }^{\circ} \mathrm{C}$ for $24 \mathrm{~h}$, the resulting solution was evaporated to dryness. The solid was dissolved in water $(60 \mathrm{~mL})$ and then the aqueous solution was acidified by conc. $\mathrm{HCl}(\mathrm{pH} 1)$. White precipitate was filtered, washed with water, and then dried. The product was obtained by recrystallization from $\mathrm{EtOH}$. Yield: $0.6 \mathrm{~g}, 68 \%$; decomposition $>250{ }^{\circ} \mathrm{C} .{ }^{1} \mathrm{H}$ NMR $\left(\mathrm{DMSO}-d_{6}\right): \delta 0.89\left(\mathrm{t}, 3 \mathrm{H}, \mathrm{CH}_{3}\right), 1.3\left(\mathrm{~m}, 10 \mathrm{H},\left(\mathrm{CH}_{2}\right)_{5}\right)$, $1.7\left(\mathrm{~m}, 2 \mathrm{H}, \underline{\mathrm{CH}}_{2} \mathrm{CH}_{2} \mathrm{O}\right), 2.5(\mathrm{~s}, 1 \mathrm{H}, \mathrm{OH}), 4.0(\mathrm{t}, J 6.4 \mathrm{~Hz}$, $\left.2 \mathrm{H}, \mathrm{CH}_{2} \mathrm{O}\right), 7.0(\mathrm{~d}, J 8.6 \mathrm{~Hz}, 2 \mathrm{H}, \mathrm{Ar}), 7.5(\mathrm{~d}, J 8.8 \mathrm{~Hz}, 2 \mathrm{H}$, Ar), 7.6 (d, J $8.2 \mathrm{~Hz}, 2 \mathrm{H}, \mathrm{Ar}), 8.0(\mathrm{~d}, J 8.2 \mathrm{~Hz}, 2 \mathrm{H}, \mathrm{Ar})$. ${ }^{13} \mathrm{C}$ NMR (DMSO- $d_{6}$ ) $\delta 13.6,21.7,25.2,28.3,28.3,28.4$, $30.9,67.5,87.1,92.1,113.4,114.8,126.9,129.2,130.0$, 130.9, 132.9, 159.2, 164.0, 166.4.

\section{4-Methoxyphenyl 4'-[(4-octyloxyphenyl)ethynyl] benzoselenoate (1a)}

Tributylphosphine $(0.15 \mathrm{~mL}, 0.6 \mathrm{mmol})$ was slowly added to dichalcogenide $(0.3 \mathrm{~g}, 0.8 \mathrm{mmol})$ in anhydrous $\mathrm{CH}_{2} \mathrm{Cl}_{2}(30 \mathrm{~mL})$ and the mixture left to stir for $15 \mathrm{~min}$. 4'-[4-(Octyloxyphenyl)ethynyl]benzoic acid (4) $(0.14 \mathrm{~g}$, $0.4 \mathrm{mmol}$ ) was then added and the reaction stirred for $24 \mathrm{~h}$ at room temperature till no precipitate was visible. The reaction mixture was diluted with $\mathrm{CH}_{2} \mathrm{Cl}_{2}$ and washed with water $(50 \mathrm{~mL})$, sat. sodium bicarbonate $(2 \times 50 \mathrm{~mL})$ and water $(50 \mathrm{~mL})$. The organic layer was dried over anhydrous sodium sulfate. The solvent was evaporated and the remaining solid was purified by chromatography and recrystallization from hexane. Yield: $0.1 \mathrm{~g}, 50 \%$; (DSC) $\mathrm{Cr} 118.1{ }^{\circ} \mathrm{C} \mathrm{N} 218.8{ }^{\circ} \mathrm{C} \mathrm{I} .{ }^{1} \mathrm{H}$ NMR $\left(\mathrm{CDCl}_{3}\right): \delta 0.89(\mathrm{t}$, $\left.3 \mathrm{H}, \mathrm{CH}_{3}\right), 1.3\left(\mathrm{~m}, 10 \mathrm{H},\left(\mathrm{CH}_{2}\right)_{5}\right), 1.8\left(\mathrm{~m}, 2 \mathrm{H}, \underline{\mathrm{CH}}_{2} \mathrm{CH}_{2} \mathrm{O}\right)$, $3.85\left(\mathrm{~s}, 3 \mathrm{H}, \mathrm{CH}_{3} \mathrm{O}\right), 3.98\left(\mathrm{t}, J 6.6 \mathrm{~Hz}, 2 \mathrm{H}, \mathrm{CH}_{2} \mathrm{O}\right), 6.9$ (d, J $8.6 \mathrm{~Hz}, 2 \mathrm{H}, \mathrm{Ar}), 7.0$ (d, J $8.5 \mathrm{~Hz}$ d, $2 \mathrm{H}, \mathrm{Ar}), 7.48$ (d, J 8.6 Hz, 2H, Ar), 7.50 (d, J 8.4 Hz, 2H, Ar). $7.6(\mathrm{~d}$, $J 8.2 \mathrm{~Hz}, 2 \mathrm{H}, \mathrm{Ar}), 7.9$ (d, $J 8.1 \mathrm{~Hz}, 2 \mathrm{H}, \mathrm{Ar}) .{ }^{13} \mathrm{C} \mathrm{NMR}$ $\left(\mathrm{CDCl}_{3}\right): \delta 14.8,23.3,26.7,29.8,29.9,29.9,30.0,32.5$, 56.0, 68.8, 88.0, 94.3, 115.0, 115.3, 115.9, 116.7, 127.9, 130.2, 132.4, 134.0, 137.8, 138.5, 160.4, 161.2, 194.2. Anal. calc. for $\mathrm{C}_{30} \mathrm{H}_{32} \mathrm{O}_{3} \mathrm{Se}$ : C 69.35; H 6.21, found: $\mathrm{C}$ 68.95; H 6.65\%. IR $v_{\text {max }} / \mathrm{cm}^{-1}: 2919,2854,2281,1672,1591,1515$, 1493. 


\section{4-Methoxyphenyl 4'-[(4-octyloxyphenyl)ethynyl] benzothioate ( $6 \boldsymbol{b}$ )}

To a solution of 4-methoxythiophenol $(0.25 \mathrm{~mL}$, $2.1 \mathrm{mmol}$ ) and 4'-(4-(octyloxyphenyl)ethynylbenzoic acid (4) $(0.3 \mathrm{~g}, 0.85 \mathrm{mmol})$ in dry $\mathrm{CH}_{2} \mathrm{Cl}_{2}(50 \mathrm{~mL})$ under argon, was added 4-(dimethylamino)pyridinium $p$-toluenesulfonate (DPTS) $(0.2 \mathrm{~g}, 0.7 \mathrm{mmol})$ and $N, N^{\prime}$ dicyclohexylcarbodiimide (DCC) $(0.9 \mathrm{~g}, 4.2 \mathrm{mmol})$. The reaction mixture was stirred for $24 \mathrm{~h}$ at r.t. The crude solution was filtered and washed with $\mathrm{CH}_{2} \mathrm{Cl}_{2}(100 \mathrm{~mL})$. The filtered mixture was washed with water $(50 \mathrm{~mL})$, sat. sodium bicarbonate $(2 \times 50 \mathrm{~mL})$ and water $(50 \mathrm{~mL})$ and the organic layer was dried over anhydrous sodium sulfate. The solvent was evaporated and the remaining solid was purified by chromatography and recrystallization from hexane. Yield: $0.12 \mathrm{~g}, 30 \%$; (DSC) $\mathrm{Cr}_{1} 64.3{ }^{\circ} \mathrm{C} \mathrm{Cr}_{2} 116.9^{\circ} \mathrm{C}$ $\mathrm{N} 248.8{ }^{\circ} \mathrm{C}$ I. ${ }^{1} \mathrm{H}$ NMR $\left(\mathrm{CDCl}_{3}\right): \delta 0.82\left(\mathrm{t}, 3 \mathrm{H}, \mathrm{CH}_{3}\right), 1.3$ (m, 10H, $\left.\left(\mathrm{CH}_{2}\right)_{5}\right), 1.7\left(\mathrm{~m}, 2 \mathrm{H}, \mathrm{CH}_{2} \mathrm{CH}_{2} \mathrm{O}\right), 3.78(\mathrm{~s}, 3 \mathrm{H}$, $\left.\mathrm{CH}_{3} \mathrm{O}\right), 3.91\left(\mathrm{t}, J 6.6 \mathrm{~Hz}, 2 \mathrm{H}, \mathrm{CH}_{2} \mathrm{O}\right), 6.8(\mathrm{~d}, J 8.8 \mathrm{~Hz}, 2 \mathrm{H}$, $\mathrm{Ar}), 6.9$ (d, J 8.9 Hz d, 2H, Ar), 7.3 (d, J 8.8 Hz, 2H, Ar), 7.4 (d, J $8.8 \mathrm{~Hz}, 2 \mathrm{H}, \mathrm{Ar}), 7.5$ (d, J 8.6 Hz, 2H, Ar), 7.9 (d, $J 8.5 \mathrm{~Hz}, 2 \mathrm{H}, \mathrm{Ar}) .{ }^{13} \mathrm{C}$ NMR $\left(\mathrm{CDCl}_{3}\right): \delta 14.1,22.6,26.0$, 29.1, 29.2, 29.3, 31.8, 55.3, 68.1, 87.3, 93.4, 114.3, 114.6, 115.0, 117.6, 127.3, 129.2, 131.5, 133.2, 135.3, 136.6, 159.7, 160.8, 190.2. HRMS-ESI: $\mathrm{m} / z$ calcd. for $\mathrm{C}_{30} \mathrm{H}_{33} \mathrm{O}_{3} \mathrm{~S}$ $[\mathrm{M}+\mathrm{H}]^{+} 473.6562$, found: 473.6541. IR $v_{\max } / \mathrm{cm}^{-1}: 2920$, 2852, 2216, 1667, 1587, 1513, 1494.

\section{4-Methoxyphenyl 4'-[(4-octyloxyphenyl)ethynyl] benzoate $(\mathbf{6 a})$}

An experimental procedure identical to $6 \mathbf{b}$ was applied. Yield: $0.5 \mathrm{~g}, 72 \%$; (DSC) $\mathrm{Cr} 128.6{ }^{\circ} \mathrm{C} \mathrm{N} 219.3{ }^{\circ} \mathrm{C}$ I. ${ }^{1} \mathrm{H} \mathrm{NMR}\left(\mathrm{CDCl}_{3}\right): \delta 0.82\left(\mathrm{t}, 3 \mathrm{H}, \mathrm{CH}_{3}\right), 1.4\left(\mathrm{~m}, 10 \mathrm{H},\left(\mathrm{CH}_{2}\right)_{5}\right)$, $1.7\left(\mathrm{~m}, 2 \mathrm{H}, \mathrm{CH}_{2} \mathrm{CH}_{2} \mathrm{O}\right), 3.76\left(\mathrm{~s}, 3 \mathrm{H}, \mathrm{CH}_{3} \mathrm{O}\right), 3.91$ (t, J 6.6 $\left.\mathrm{Hz}, 2 \mathrm{H}, \mathrm{CH}_{2} \mathrm{O}\right), 6.8(\mathrm{~d}, J 8.9 \mathrm{~Hz}, 2 \mathrm{H}, \mathrm{Ar}), 6.9(\mathrm{~d}, J 9.0 \mathrm{~Hz}$ d, 2H, Ar), 7.1 (d, J 9.1 Hz, 2H, Ar), 7.4 (d, J $8.9 \mathrm{~Hz}, 2 \mathrm{H}$, Ar), $7.5(\mathrm{~d}, J 8.6 \mathrm{~Hz}, 2 \mathrm{H}, \mathrm{Ar}), 8.1(\mathrm{~d}, J 8.6 \mathrm{~Hz}, 2 \mathrm{H}, \mathrm{Ar}) .{ }^{13} \mathrm{C}$ NMR $\left(\mathrm{CDCl}_{3}\right): \delta 14.1,22.6,25.9,29.1,29.2,29.3,31.8$, 55.6, 68.1, 87.4, 93.2, 114.3, 114.5, 114.6, 122.4, 128.4, 129.1, 130.0, 131.3, 133.2, 144.3, 157.3, 159.7, 165.0. HRMS-ESI: $m / z$ calcd. for $\mathrm{C}_{30} \mathrm{H}_{33} \mathrm{O}_{4}[\mathrm{M}+\mathrm{H}]^{+} 457.5856$, found: 457.5842. IR $v_{\max } / \mathrm{cm}^{-1}: 2876,2808,2167,1692$, 1556, 1458, 1427.

\section{Results and Discussion}

Scheme 1 outlines the synthesis of the key intermediate 4 starting with the preparation of the acetylene 2 , which synthesis has been described previously. ${ }^{9}$ Thus the alkylation of $p$-bromophenol with 1-bromooctane gave the corresponding alkylaryl ether (7) in $81 \%$ yield. Sonogashira reaction ${ }^{11}$ of the alkylaryl ether with 2-methyl-3-butyn-2ol (mebynol), followed by deprotection using $\mathrm{KOH}$ and isopropyl alcohol furnished the acetylene 2. ${ }^{12}$ Finally, through a second Sonogashira reaction of the acetylene derivative $\mathbf{2}$ and methyl 4-bromobenzoate (3), compound 4 was obtained after hydrolysis in satisfactory yields.

Having obtained the acid 4, we concentrated our efforts on the synthesis of the target molecules. In this way, the resulting acid $\mathbf{4}$ was converted into chalcogeno esters $\mathbf{6 a}$ and $\mathbf{6 b}$ by reaction with the corresponding phenol or thiol in classical conditions. Both final products were characterized by spectroscopic means and their structures are consistent with the spectral data.

The thermal transitions and enthalpies of the chalcogeno esters 1a, 6a, and $\mathbf{6 b}$ were investigated by differential scanning calorimetry (DSC) and polarizing optical microscopy (POM) and the results are tabulated in Table 1. The transition temperatures and enthalpy values were collected from the second heating scan. The texture of the mesophase was identified by microscopy studies and compared with pictures according reference $13 .{ }^{13}$ All chalcogen-LC display the nematic phase which is expected for derivatives with short alkyl chains. ${ }^{14}$ The presence of small polar methoxy group bonded to a conjugated core increases the effective length of the mesogen without affecting its breadth significantly. The DSC traces of chalcogeno esters 1a, $6 \mathbf{a}$ and $\mathbf{6 b}$ showed that all samples were thermally stable. The two reversible peaks observed in DSC traces are associated with Crystal $(\mathrm{Cr}) \rightarrow$ Nematic $(\mathrm{N})$ and Nematic $(\mathrm{N}) \rightarrow$ Isotropic (I) transitions, respectively (Figure 2). On cooling from its

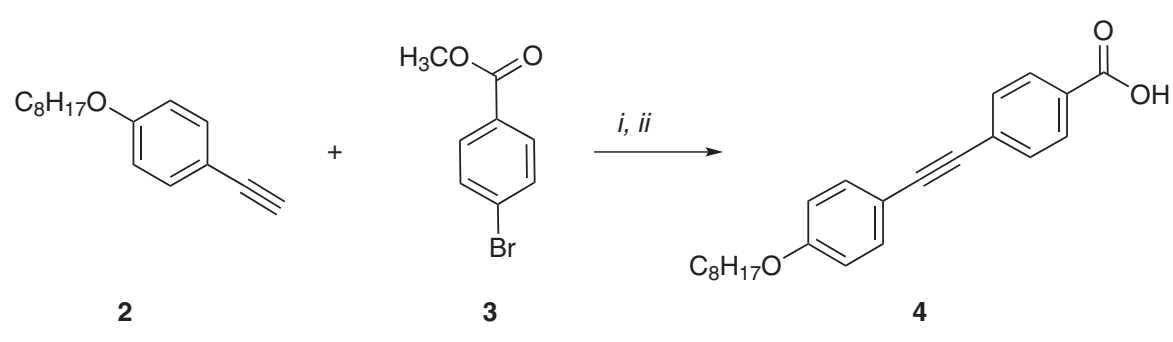

Scheme 1. Synthesis of the key intermediate 4. Reactions conditions: $i: \mathrm{PdCl}_{2}\left(\mathrm{PPh}_{3}\right)_{2}, \mathrm{Et}_{3} \mathrm{~N}, \mathrm{CuI}, \mathrm{PPh}_{3}(48 \%) ; i$ : KOH 1 mol L-1, THF, reflux, then conc. $\mathrm{HCl}(68 \%)$. 

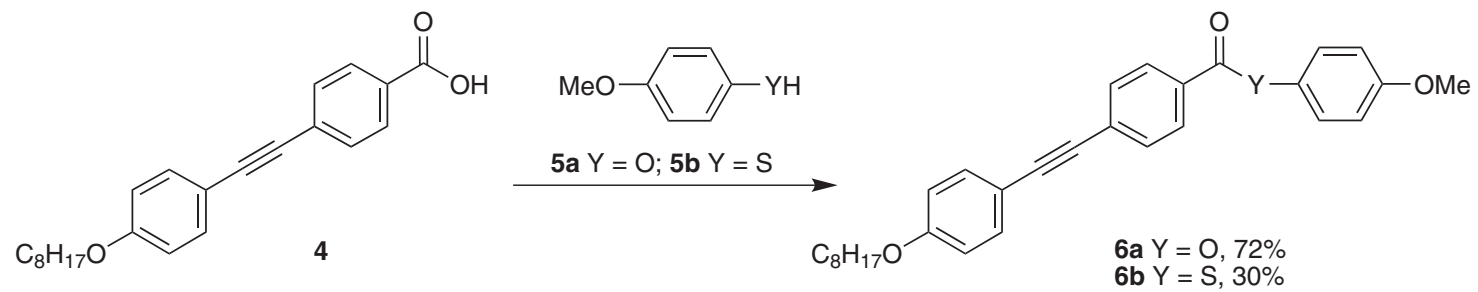

Scheme 2. Synthesis of the chalcogenoesters $6 \mathbf{a}$ and $\mathbf{6 b}$. Reactions conditions: DCC, DPTS, $\mathrm{CH}_{2} \mathrm{Cl}_{2}$, r.t.

isotropic phase, the samples enter into nematic phase with a thread-like texture. An illustration of a nematic phase texture found in chalcogeno esters is inserted in Figure 2. This texture is usually observed in thin samples placed between two crossed polarizers. The dark lines, the so-called threads, are singularity lines which either connect two point defects or form closed loops. The planar thread-like texture is characteristic of liquidcrystalline nematic phases.

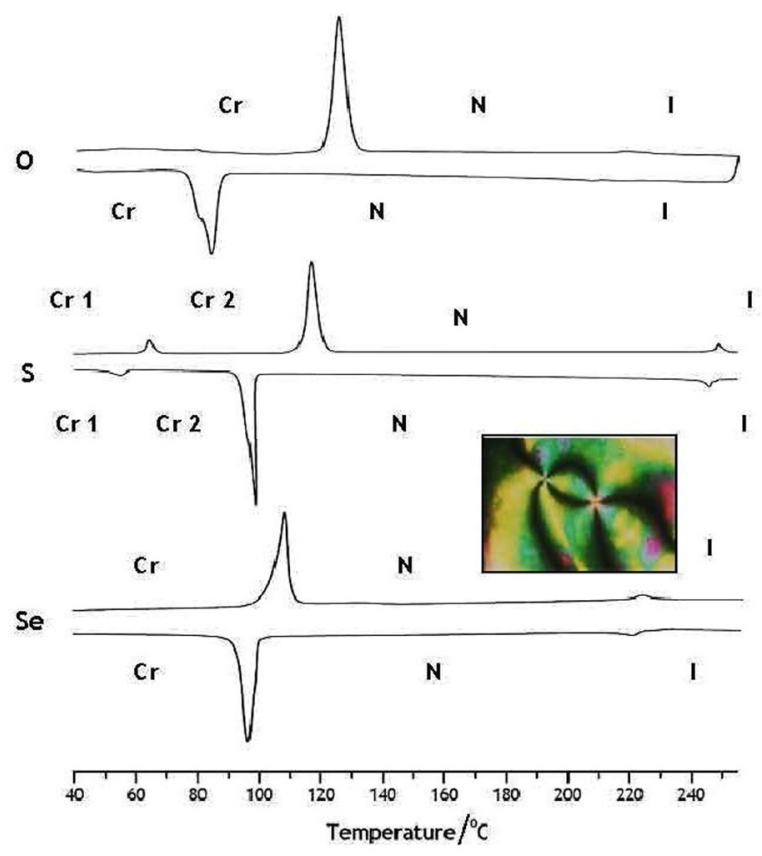

Figure 2. DSC traces of chalcogeno esters LC for rates of $10^{\circ} \mathrm{C} \mathrm{min}^{-1}$; $2^{\text {nd }}$ heating and cooling runs are shown; $\mathrm{Cr}-$ crystal phase; $\mathrm{N}-$ nematic phase; I - isotropic phase. Inner figure: Optical micrograph between crossed polarizers of schlieren texture in the nematic phase.

From Table 1 we can see that chalcogeno esters showed a wide phase transition temperature range for all compounds in this study. The enthalpy values for these LC compounds are in agreement with a less ordered nematic phase. The LC-6b has displays a widest temperature range melting at $116.9^{\circ} \mathrm{C}$ to mesophase and to isotropic liquid at $248.8^{\circ} \mathrm{C}$ $\left(\Delta T=131.1^{\circ} \mathrm{C}\right)$, and in addition LC-6b have the highest enthalpy value in this series. The clearing temperatures increase in the order $\mathrm{S}>\mathrm{O} \cong \mathrm{Se}$, suggesting that the polarizability of chalcogen atom is an important factor in relation to the mesophase stability. However, the melting temperature of each chalcogeno ester is in the order: $\mathrm{O}>\mathrm{S}>$ Se (Table 1). Probably, in the crystalline state the molecular interaction is more effective to the more electronegative chalcogen, which helps to stabilize the packing of molecules, favoring in this way the compound $O$-ester $\mathbf{6 a}$.

Table 1. Phase transition temperatures $\left({ }^{\circ} \mathrm{C}\right)$ for chalcogeno esters-LC 6a, 6b, 1a and enthalpy values ${ }^{\mathrm{a}}\left(\Delta H \mathrm{kcal} \mathrm{mol}^{-1}\right)$ in brackets

\begin{tabular}{|c|c|c|c|}
\hline LC & Cycle & Phase sequence & $\Delta T^{\mathrm{e}}$ \\
\hline $6 a$ & $\begin{array}{l}\text { Heating } \\
\text { Cooling }\end{array}$ & $\begin{array}{c}\mathrm{Cr} 128.6(9.0) \mathrm{N} 219.3(0.13) \mathrm{I} \\
\text { I } 210.8 \mathrm{~N} 90.2 \mathrm{Cr}\end{array}$ & 90.7 \\
\hline $6 b$ & $\begin{array}{l}\text { Heating } \\
\text { Cooling }\end{array}$ & $\begin{array}{c}\mathrm{Cr}_{1} 64.3(0.64) \mathrm{Cr}_{2} 116.9(6.88) \mathrm{N} 248.8(0.26) \mathrm{I} \\
\mathrm{I} 245.8 \mathrm{~N} 98.8 \mathrm{Cr}_{2} 55.2 \mathrm{Cr}_{1}\end{array}$ & 131.9 \\
\hline $1 a^{b}$ & $\begin{array}{l}\text { Heating } \\
\text { Cooling }\end{array}$ & $\begin{array}{c}\text { Cr } 108.1(5.00) \mathrm{N} 218.8(0.11) \mathrm{I} \\
\text { I } 216.1 \mathrm{~N} 97.0 \mathrm{Cr}\end{array}$ & 110.7 \\
\hline
\end{tabular}

${ }^{\mathrm{a} O n}$ heating; ${ }^{\mathrm{b}}$ According to reference 7 ; ${ }^{\mathrm{c}}$ on heating; $\mathrm{Cr}=$ crystal phase; $\mathrm{N}=$ nematic phase; $\mathrm{I}=$ isotropic phase.

To the liquid-crystalline state, the substitution of oxygen atom in this series by a chalcogen atom with superior atomic number having higher atomic radius and larger polarizability, enhances the intermolecular interaction after melting and thus stabilizes the mesophase. Our results are suggesting that enhancement of the clearing point of thioester $\mathbf{6 b}$ is attributed to the increasing of delocalization charge of the sulfur atom over benzene ring and to the carbonyl group; the values for the $\mathrm{C}=\mathrm{O}$ stretching vibrations listed in Table 2 are indicative of substantial resonance interaction. ${ }^{15}$ Considering our results listed in Table 1, we can see that the thermal stability of these chalcogeno esters does not follow only the $\mathrm{Se}>\mathrm{S}>\mathrm{O}$ polarizability order. ${ }^{16}$ However, the clearing temperature for selenoester 1a is lower than expected. In addition, the formation of mesophase with low symmetry depends on the structural features of the molecular framework. In this sense, we have designed a proper molecular LC having a triple bond inserted between two aryl rings and at least one terminal short alkyl chain, such as a methoxy group. 
Table 2. Spectral data of aryl chalcogeno esters $\mathrm{O}, \mathrm{S}, \mathrm{Se}$ and $\mathrm{Te}^{21}$

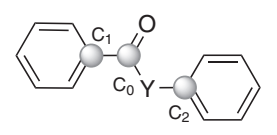

\begin{tabular}{lcccccc}
\hline $\mathrm{Y}$ & $v \mathrm{C}=\mathrm{O}$ & $v^{\mathrm{a}} \mathrm{C}=\mathrm{O}$ & $\delta^{\mathrm{b}}{ }^{13} \mathrm{C}-\mathrm{C}_{1}$ & $\delta^{\mathrm{b}}{ }^{13} \mathrm{C}-\mathrm{C}_{0}$ & $\delta^{\mathrm{b} 13} \mathrm{C}-\mathrm{C}_{2}$ & Eletroneg. $^{\mathrm{c}}$ \\
\hline $\mathrm{O}$ & 1735 & 1788 & 129.6 & 164.3 & 151.0 & 3.44 \\
$\mathrm{~S}$ & 1675 & 1745 & 136.6 & 189.7 & 127.6 & 2.58 \\
$\mathrm{Se}$ & 1686 & 1759 & 138.4 & 192.7 & 125.8 & 2.55 \\
$\mathrm{Te}$ & 1682 & 1753 & 142.6 & 196.0 & 113.6 & 2.10 \\
\hline
\end{tabular}

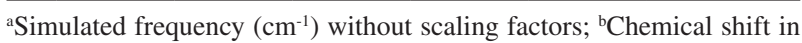
ppm; 'Pauling scale.

To investigate the origin of this behavior a theoretical study was performed using a DFT/B3LYP calculations with Becke's three-parameter hybrid method ${ }^{17}$ using the Lee-Yang-Parr correlation functional ${ }^{18}$ (B3LYP) with DGDZVP $^{19}$ basis set. All quantum chemical calculations were performed with the Gaussian package. ${ }^{20}$ All geometries were full optimized to a minimum, and, in order to check if there is any imaginary frequency, we have performed force constant calculations.

Table 3 contains some selected data obtained by theoretical calculations and in Table 2 are compiled some spectral values collected from literature of IR and NMR spectrum in order to establish a comparative analysis. ${ }^{21}$ The $\mathrm{O}=\mathrm{C}-\mathrm{Y}$ and $\mathrm{Y}-\mathrm{C}_{\mathrm{sp} 2}$ bond distances of the chalcogeno esters $\mathrm{O}, \mathrm{S}, \mathrm{Se}$ and $\mathrm{Te}$ increase as the atomic radius increases in the order $\mathrm{Te}>\mathrm{Se}>\mathrm{S}>\mathrm{O}$. The calculated dipole moments also follow the same tendency in spite of the decreasing eletronegativity (in brackets) down the groups in the periodic table: $\mathrm{O}(3.44)>\mathrm{S}(2.58)>\mathrm{Se}$ $(2.55)>\mathrm{Te}$ (2.10). Interesting to note that the $\mathrm{O}=\mathrm{C}-\mathrm{Y}-\mathrm{C}_{\mathrm{sp} 2}$ angle decreases with decreasing electronegativity of the chalcogen atom. The deviation angles observed for these compounds occur because of a slightly different hybridization of the chalcogen atom when bonded to two groups. So, as the $\mathrm{O}=\mathrm{C}-\mathrm{Y}-\mathrm{C}_{\mathrm{sp} 2}$ angle decreases, the lone pairs on chalcogen atoms have more $s$ character which contributes to increase the polarizability in the order $\mathrm{Te}>$ $\mathrm{Se}>\mathrm{S}>\mathrm{O}$. The polarizability calculations show that the higher the chalcogen atomic number the greater will be the polarizability of the molecule. This information can be used to explain the chemical shift observed in Table 2 for these compounds.

The highest occupied and the lowest unoccupied molecular orbital (HOMO and LUMO, respectively) energies and energy band gap (LUMO-HOMO energy difference, $\Delta \mathrm{E}$ ) are given in Table 3 . The energy band gaps close as the chalcogen atomic number increases. UV-Vis data in solution ( $c a .10^{-5} \mathrm{~mol} \mathrm{~L}^{-1}$ ) was applied in order to obtain the HOMO-LUMO gap for further comparison with the theoretical results. The calculated values to the HOMO-LUMO gap are in excellent agreement with the experimental results in which the electronegativity of the heteroatom $(\mathrm{O}, \mathrm{S}$ and $\mathrm{Se})$ seems to play a fundamental role in the absorption maxima.

The absorption maxima for $\mathbf{1 a}, \mathbf{6} \mathbf{b}$ and $\mathbf{6 a}$ are observed at 341,337 and $324 \mathrm{~nm}$, respectively, which are clearly shifted to longer wavelengths (bathocromic effect) related with polarizability of the chalcogen atoms. The absorption maximum of selenol ester 1a is slightly red-shifted relative to $\mathbf{6 b}$, but it is red-shifted at $17 \mathrm{~nm}$ relative to $\mathbf{6 a}$. These data suggest that increasing the electronegativity of the heteroatom causes a hypsochromic effect indicating that the electrons are tighter in the molecular structure. Concerning the $\varepsilon_{\text {max }}$ values, the ester and thioester compounds present a similar planar structure in comparison with the selenoester which presents the higher one, as revealed by the chalcogen coefficients of the HOMO (Figure 3).

Figure 3 shows the HOMO of the chalcogeno esters O, $\mathrm{S}, \mathrm{Se}$ and Te. Both the HOMO and LUMO (Supplementary Information, SI) levels are of $\pi$ nature and spread over the tolan group which is responsible for absorption of

Table 3. Selected molecular modeling data for chalcogeno esters O (6a), S (6b), Se (1a) and Te

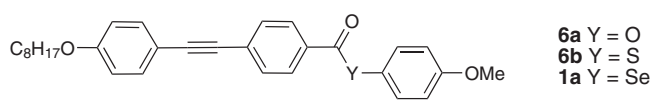

\begin{tabular}{|c|c|c|c|c|c|c|c|c|c|}
\hline \multirow{2}{*}{$\mathrm{Y}$} & \multirow{2}{*}{$\mathrm{d}_{\mathrm{O}=\mathrm{C}-\mathrm{Y}}(\AA)$} & \multirow{2}{*}{$\mathrm{d}_{\mathrm{Csp2-Y}}(\AA)$} & \multirow{2}{*}{$\mathrm{E}_{\text {номо }}(\mathrm{eV})$} & \multirow{2}{*}{$\mathrm{E}_{\text {LUмо }}(\mathrm{eV})$} & \multicolumn{2}{|c|}{$\Delta \mathrm{E}_{\text {(номо-LUMO) }}$} & \multirow{2}{*}{$\mu(D)$} & \multirow{2}{*}{$\varepsilon_{\max }$} & \multirow{2}{*}{$\begin{array}{c}\text { Angle }_{\mathrm{O}=\mathrm{C}-\mathrm{Y}-\mathrm{Csp}} \\
\left(^{\circ}\right)\end{array}$} \\
\hline & & & & & DFT/B3LYP & Exp. $^{\mathrm{a}}$ & & & \\
\hline $\mathrm{O}$ & 1.375 & 1.402 & -5.826 & -2.058 & 3.768 & 3.803 & 3.64 & 3.26 & 118.8 \\
\hline S & 1.829 & 1.791 & -5.837 & -2.161 & 3.676 & 3.646 & 4.09 & 3.62 & 100.9 \\
\hline $\mathrm{Se}$ & 1.994 & 1.934 & -5.853 & -2.217 & 3.636 & 3.614 & 4.36 & 6.59 & 97.5 \\
\hline $\mathrm{Te}$ & 2.224 & 2.141 & -5.807 & -2.273 & 3.534 & - & 4.54 & & 93.8 \\
\hline
\end{tabular}

${ }^{a}$ Experimental values for chalcogeno esters $\mathrm{O}(\mathbf{6 a}), \mathrm{S}(\mathbf{6 b})$ and Se (1a) were obtained at $\lambda_{\text {max }}=324,337$ and $341 \mathrm{~nm}$, respectively. 

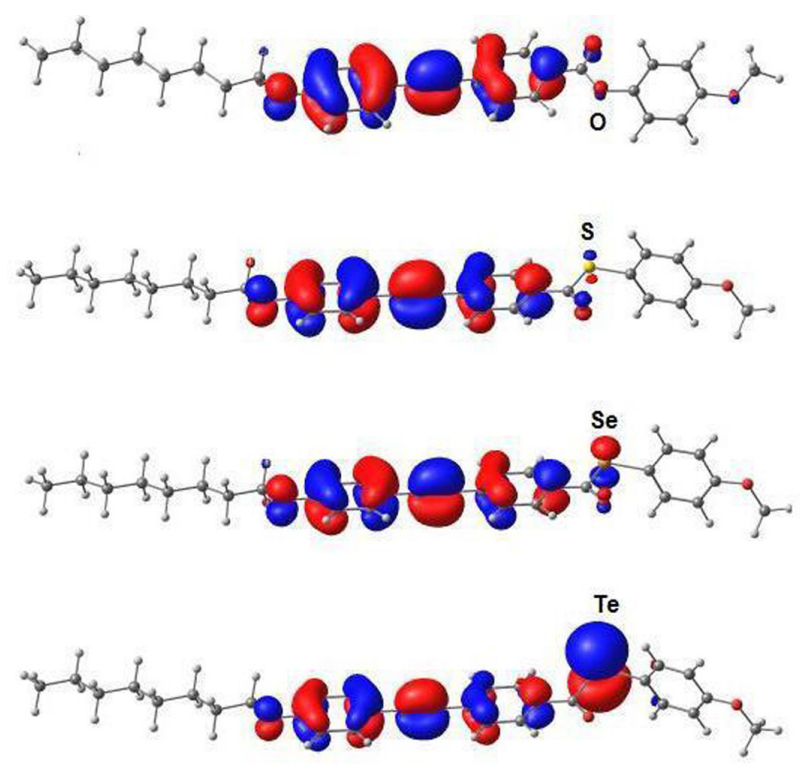

Figure 3. HOMOs of chalcogeno esters O (6a), S (6b), Se (1a) and Te calculated with DFT at B3LYP/DGDZVP level.

ultraviolet radiation. It is interesting to note that both HOMO and LUMO orbitals present nodes along the long molecular axis. We can see that the aryl substitution directly on the chalcogen does not have a greater effect on the HOMO and LUMO energies, since the corresponding wave functions do not have contributions from the aryl substituents; hence, aryl substituents on the chalcogens are not expected to induce any significant alteration on the electronic properties of the chalcogen $\mathrm{O}, \mathrm{S}, \mathrm{Se}$ and Te. In contrast to the electronic properties, aryl substitution has an effect on the LC properties. Our results are suggesting that the thiol $\mathbf{6 b}$ is better than selenol $\mathbf{1 a}$ in stabilizing the LC mesophase. The smaller mesophase range of 1a compared to thiol $\mathbf{6 b}$ could be related with the reduced $\pi$-conjugation of chalcogen-benzene ring due to the high energy level of $4 d$ orbital of the selenol 1a.

\section{Conclusions}

In summary, we have shown a practical and concise synthesis of an homologous series chalcogeno esters by an easy, straightforward and flexible synthetic route. The thermotropic liquid crystalline properties were investigated by DSC and POM analysis The final chalcogeno esters 1a, 6a and $\mathbf{6 b}$ exhibited a stable and large nematic mesophase range. In addition, the calculated values to the HOMO-LUMO gap are in excellent agreement with the experimental results in which the electronegativity of the heteroatom $(\mathrm{O}, \mathrm{S}$ and $\mathrm{Se})$ seems to play a fundamental role in the absorption maxima.

\section{Supplementary Information}

Supplementary data are available free of charge at http://jbcs.sbq.org.br, as pdf file.

\section{Acknowledgments}

We are grateful to the CAPES, CNPq, INCT-CMN and FAPERGS for financial support. CAPES is also acknowledged for PhD fellowship for D. S. R.

\section{References}

1. Zeni, G.; Lüdtke, D. S.; Panatieri, R. B.; Braga, A. L.; Chem. Rev. 2006, 106, 1032; Zeni, G.; Braga, A. L.; Stefani, H. A.; Acc. Chem. Res. 2003, 36, 731; Wirth, T.; Freudendahl, D. M.; Shahzad, S. A.; Eur. J. Org. Chem. 2009, 1649; Perin, G.; Lenardão, E. J.; Jacob, R. G.; Panatieri, R. B.; Chem. Rev. 2009, 109, 1277; Oliveira, J. M.; Palmeira, J. P.; Comasseto, J. V.; Menezes, P. H.; J. Braz. Chem. Soc. 2010, 21, 366; Silva, M. S.; Santos, A. A.; Comasseto, J. V.; Tetrahedron Lett. 2009, 50,6498 .

2. Organoselenium Chemistry: Wirth, T.; Topics in Current Chemistry 208, Sringer-Verlag: Heidelberg, 2000; Krief, A. In Compreensive Organomettalic Chemistry II; Abel, E. V.; Stone, F. G. A.; Wilkinson, G., eds, Pergamon Press: New York, 1995, Vol. 11, Chapter 13; Paulmier, C. In Organic Chemistry Series 4; Baldwin, E. J. ed., Pergamon Press: Oxford, 1986.

3. Some examples: Wirth, T.; Tetrahedron Lett. 1995, 36, 7849; Wirth, T.; Angew. Chem. Int. Ed. 2000, 39, 3740; Braga, A. L.; Paixão, M. W.; Lüdtke, D. S.; Silveira, C. C.; Rodrigues, O. E. D.; Org. Lett. 2003, 5, 2635; Braga, A. L.; Silveira, C. C.; de Bolster, M. G. W.; Schrekker H. S.; Wessjohann, L. A.; Schneider, P. H.; J. Mol. Catal. A 2005, 239, 235; Braga, A. L.; Paixão, M. W.; Westermann, B.; Schneider, P. H.; Wessjohann, L. A.; J. Org. Chem. 2008, 73, 2879; Schneider, P. H.; Schrekker, H. S.; Silveira, C. C.; Wessjohann, L. A.; Braga, A. L.; Eur. J. Org. Chem. 2004, 2715; Braga, A. L.; Lüdtke, D. S.; Wessjohann, L. A.; Paixão, M. W.; Schneider, P. H.; J. Mol. Catal. A 2005, 229, 47.

4. Mugesh, G.; du Mont, W. -W.; Sies, H.; Chem. Rev. 2001, 101, 2125; Nogueira, C. W.; Zeni, G.; Rocha, J. B. T.; Chem. Rev. 2004, 104, 6255.

5. Stadman, T. C.; Аnnu. Rev. 1996, 65, 83.

6. Heppke, G.; Martens, J.; Praefcke, K.; Simon, H.; Angew. Chem. Int. Ed. 1977, 16, 318; Crouch, D. J.; Skabara, P. J.; Lohr, J. E.; McDouall, J. J. W.; Heeney, M.; McCulloch, I.; Sparrowe, D.; Shkunov, M.; Coles; S. J.; Horton, P. N.; Hursthouse M. B.; Chem. Mater. 2005, 17, 6567; Santos M. J. L.; Girotto, E. M.; J. Braz. Chem. Soc. 2009, 2, 229. 
7. Rampon, D. S.; Rodembuch, F. S.; Schneider, J. M. F. M.; Bechtold, I. H.; Gonçalves, P. F. B.; Merlo, A. A.; Schneider, P. H.; J. Mater. Chem. 2010, 20, 715.

8. Dewar, M. J. S.; Riddle, R. M.; J. Am. Chem. Soc. 1975, 97, 6658; Ohulchanskyy, T. Y.; Donnelly, D. J.; Detty, M. R.; Prasad, P.; J. Phys. Chem. B 2004, 108, 8668; Detty, M. R.; Merkel, P. B.; J. Am. Chem. Soc. 1990, 112, 3845; Shimizu, Y.; Oikawa, K.; Nakayama, K-I.; Guillon, D.; J. Mater. Chem. 2007, 17, 4223; Lepeltier, M.; Hiltz, J.; Lockwood, T.; Belanger-Gariepy, F.; Perepichka, D. F.; J. Mater. Chem. 2009, 19, 5167.

9. Vasconcelos, U. B.; Dalmolin, E.; Merlo, A. A.; Org. Lett. 2005 , 7, 1027; Vasconcelos, U. B.; Merlo, A. A.; Synthesis 2006, 7, 1141; Vasconcelos, U. B.; Vilela, G. D.; Schrader, A.; Borges, A. C. A.; Merlo, A. A.; Tetrahedron 2008, 64, 4619; Merlo, A. A.; Gallardo, H.; Taylor, T. R.; Quim. Nova 2001, 24, 354.

10. Suzuki, M.; Sato, T.; Kurose, A.; Shirai, H.; Hanabusa, K.; Tetrahedron Lett. 2005, 46, 2741.

11. Sonogashira, K.; Tohda, Y.; Hagihara, N.; Tetrahedron Lett. 1975, 16, 4467; Chinchilla, R.; Nájera, C.; Chem. Rev. 2007, 107, 874; Cristiano, R.; Santos, D. M. P. O.; Conte, G.; Gallardo, H.; Liq. Cryst. 2006, 33, 997; Price, D. M.; Dirk, S. M.; Maya, F.; Tour, J. M.; Tetrahedron 2003, 59, 2497; Rajendra, M. S.; Neves Filho, R. A.; Schneider, R.; Vieira, A. A.; Gallardo, H.; Liq. Cryst. 2008, 32, 737; Gallardo, H.; Cristiano, R.; Vieira, A. A.; Neves Filho, R. A.; Srivastava, R. M.; Synthesis 2008, 4, 605; Gallardo, H.; Cristiano, R.; Vieira, A. A.; Neves Filho, R. A.; Srivastava, R. M.; Bechtold, I. H.; Liq. Cryst. 2008, 35, 857; Tavares, A.; Schneider, P. H.; Merlo, A. A.; Eur. J. Org. Chem. 2009, 6, 889; Passo, J. A.; Vilela, G. D.; Schneider, P. H.; Ritter, O. M. S.; Merlo, A. A.; Liq. Cryst. 2008, 35, 833.

12. Melissaris, A. P.; Litt, M. H.; Macromolecules 1994, 27, 883; Tavares, A.; Livotto, P. R.; Goncalves, P. F. B.; J. Braz. Chem. Soc. 2009, 9, 1742.

13. Gray, G. W.; Goodby, J. W.; Smectic Liquid Crystals: Textures and Structures, Leonard Hill: Glasgow and London, 1984; Dierking, I.; Textures of Liquid Crystals; Wiley-VCH Verlag GmbH \& Co. KGaA: Weinheim, 2003.
14. Skelton, G. W.; Dong, D.; Tuffin, R. P.; Kelly, S. M.; J. Mat. Chem. 2003, 13, 450.; Hird, M.; Toyne, K. J.; Liq. Cryst. 1993, 14, 741 .

15. Petrov, V. F.; Mol. Cryst. Liq. Cryst. 2005, 442, 63.

16. Izawa, T.; Miyazaki, E.; Takimiya, K.; Chem. Mater. 2009, 21, 903.

17. Becke, A. D.; J. Chem. Phys. 1996, 104, 1040.

18. Lee, C.; Yang, W.; Par, R. G.; Phys. Rev. B 1988, 37, 785.

19. Sosa, C.; Andzelm, J.; Elkin, B. C.; Wimmer, E.; Dobbs, K. D.; Dixon, D. A.; J. Phys. Chem. 1992, 96, 6630.

20. Frisch, M. J.; Trucks, G. W.; Schlegel, H. B.; Scuseria, G. E.; Robb, M. A.; Cheeseman, J. R.; Montgomery, Jr., J. A.; Vreven, T.; Kudin, K. N.; Burant, J. C.; Millam, J. M.; Iyengar, S. S.; Tomasi, J.; Barone, V.; Mennucci, B.; Cossi, M.; Scalmani, G.; Rega, N.; Petersson, G. A.; Nakatsuji, H.; Hada, M.; Ehara, M.; Toyota, K.; Fukuda, R.; Hasegawa, J.; Ishida, M.; Nakajima, T.; Honda, Y.; Kitao, O.; Nakai, H.; Klene, M.; Li, X.; Knox, J. E.; Hratchian, H. P.; Cross, J. B.; Bakken, V.; Adamo, C.; Jaramillo, J.; Gomperts, R.; Stratmann, R. E.; Yazyev, O.; Austin, A. J.; Cammi, R.; Pomelli, C.; Ochterski, J. W.; Ayala, P. Y.; Morokuma, K.; Voth, G. A.; Salvador, P.; Dannenberg, J. J.; Zakrzewski, V. G.; Dapprich, S.; Daniels, A. D.; Strain, M. C.; Farkas, O.; Malick, D. K.; Rabuck, A. D.; Raghavachari, K.; Foresman, J. B.; Ortiz, J. V.; Cui, Q.; Baboul, A. G.; Clifford, S.; Cioslowski, J.; Stefanov, B. B.; Liu, G.; Liashenko, A.; Piskorz, P.; Komaromi, I.; Martin, R. L.; Fox, D. J.; Keith, T.; Al-Laham, M. A.; Peng, C. Y.; Nanayakkara, A.; Challacombe, M.; Gill, P. M. W.; Johnson, B.; Chen, W.; Wong, M. W.; Gonzalez, C.; Pople, J. A.; Gaussian 03, Revision C.02, Gaussian, Inc.: Wallingford CT, 2004.

21. Kingsbury, C. A.; Ebert, G.; Phosphorus, Sulfur Silicon Relat. Elem. 1981, 9, 315; Piette, J. L.; Deberg, D.; Baiwir, M.; Llabres, G.; Spectrochim. Acta 1980, 36A, 769; Llabres, G.; Baiwir, M.; Spectrochim. Acta 1982, 38A, 595.

Submitted: April 19, 2010 Published online: July 13, 2010 


\title{
An Evaluation of the Chalcogen Atom Effect on the Mesomorphic and Electronic Properties in a New Homologous Series of Chalcogeno Esters
}

\author{
Daniel S. Rampon, ${ }^{a}$ Fabiano S. Rodembusch, ${ }^{a}$ Paulo F. B. Gonçalves, ${ }^{b}$ \\ Rogério V. Lourega, ${ }^{c}$ Aloir A. Merlo ${ }^{*, a}$ and Paulo H. Schneider ${ }^{*, a}$
}

aInstituto de Química, Universidade Federal do Rio Grande do Sul, CP 15003, 91501-970 Porto Alegre-RS, Brazil

${ }^{b}$ Instituto de Química, Centro Universitário La Salle. Av. Victor Barreto, 2288. Centro, 92010-000 Canoas-RS, Brazil

${ }^{c}$ Faculdade de Química, Pontifícia Universidade Católica do Rio Grande do Sul, Av. Ipiranga, 6681, Partenon, 90619-900 Porto Alegre-RS, Brazil

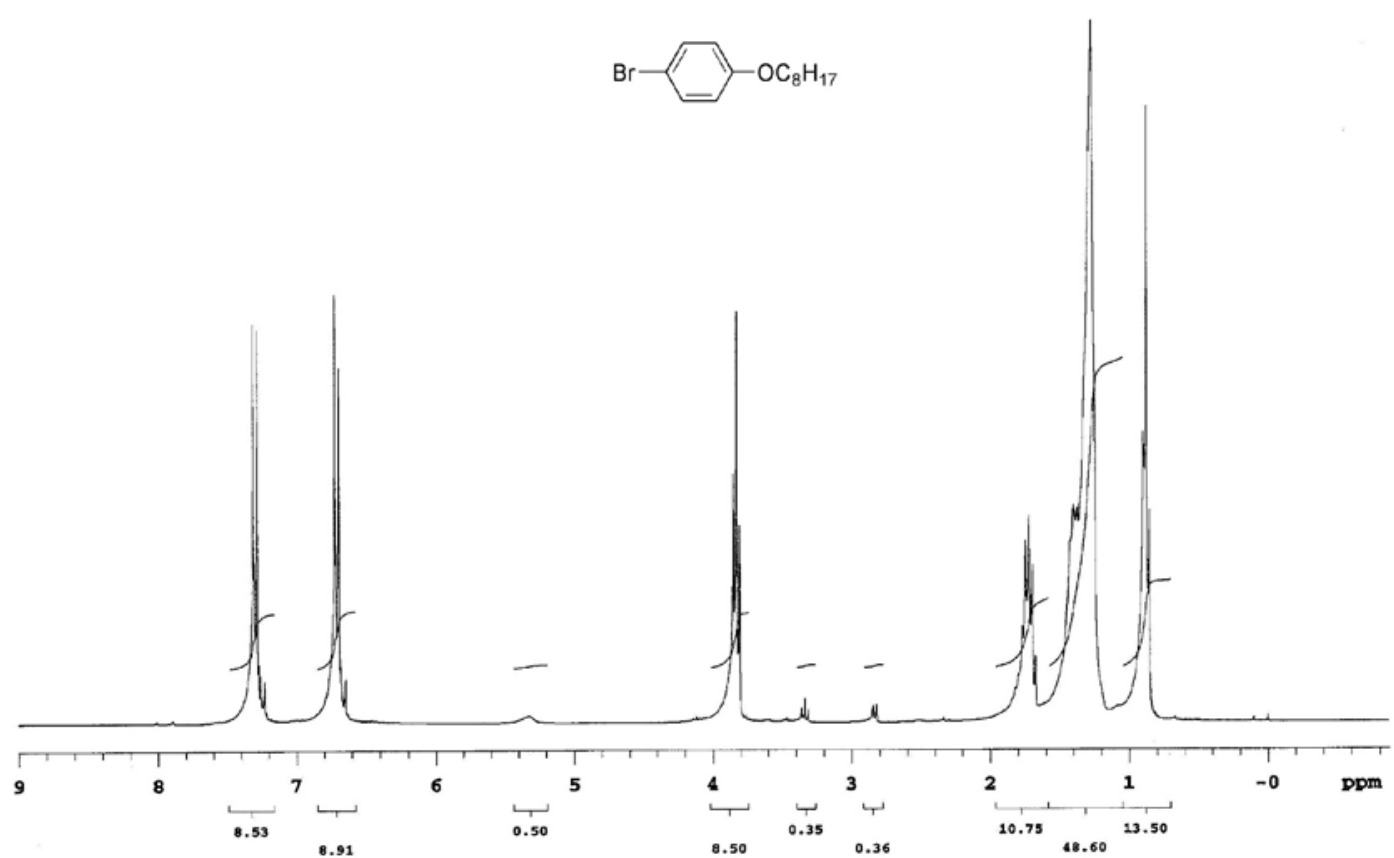

Figure S1. ${ }^{1} \mathrm{H}$ NMR spectrum of compound 1-bromo-4-octyloxybenzene (7) $\left(\mathrm{CDCl}_{3}, 300 \mathrm{MHz}\right)$. 


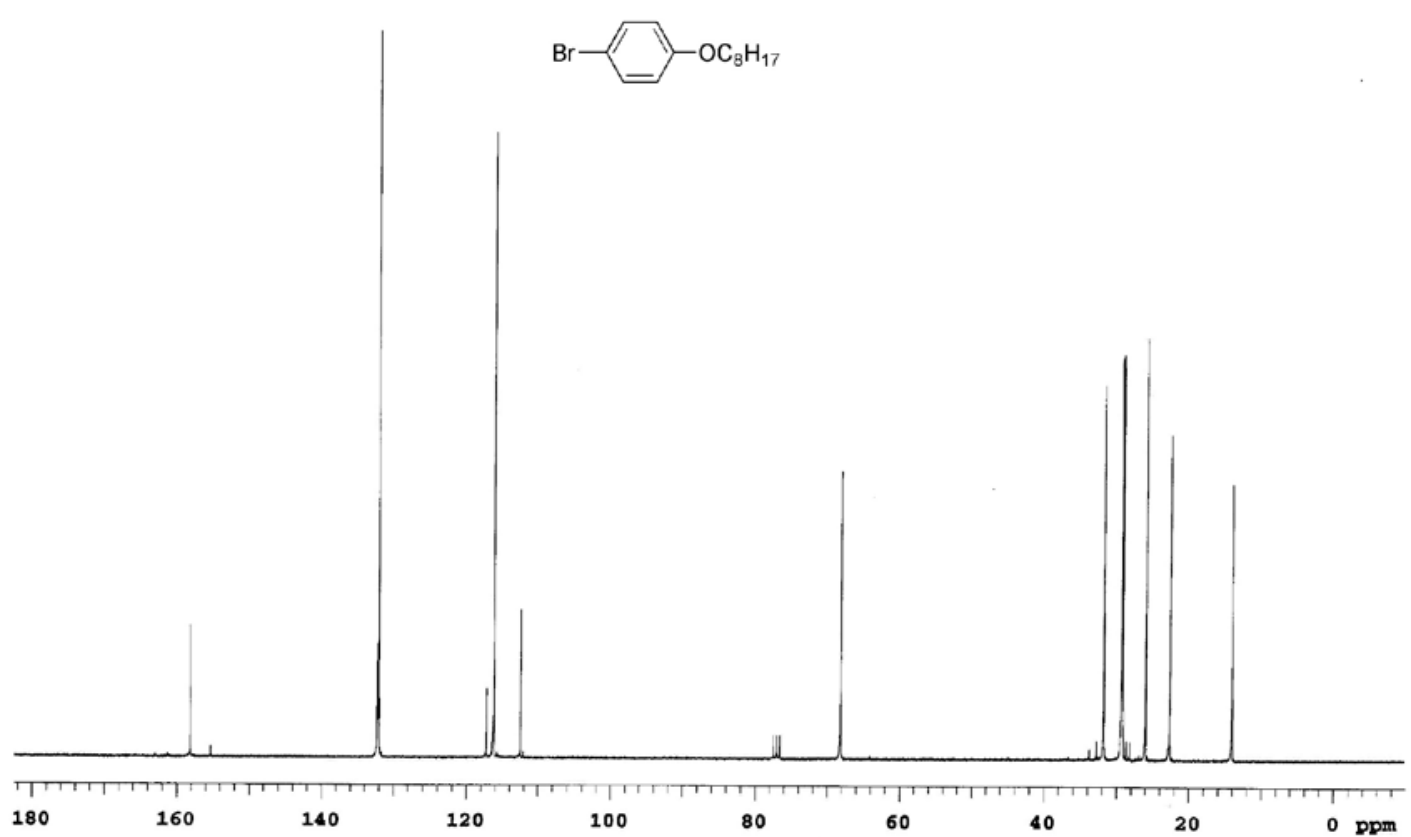

Figure S2. ${ }^{13} \mathrm{C}$ NMR spectrum of compound 1-bromo-4-octyloxybenzene (7) $\left(\mathrm{CDCl}_{3}, 75 \mathrm{MHz}\right)$.

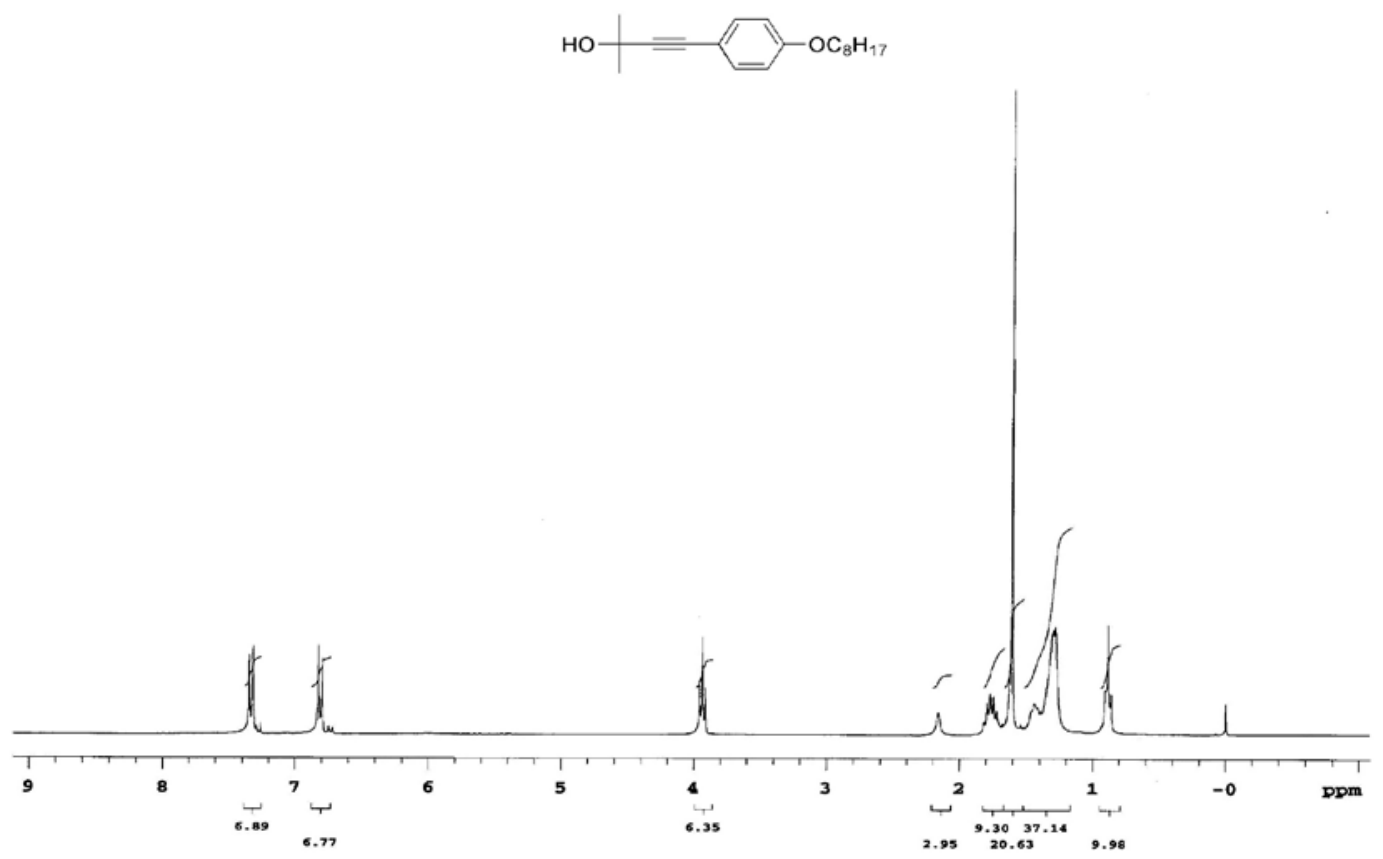

Figure S3. ${ }^{1} \mathrm{H}$ NMR spectrum of compound 4-(4-octyloxyphenyl)-2-methylbut-3-yn-2-ol (8) $\left(\mathrm{CDCl}_{3}, 300 \mathrm{MHz}\right)$. 


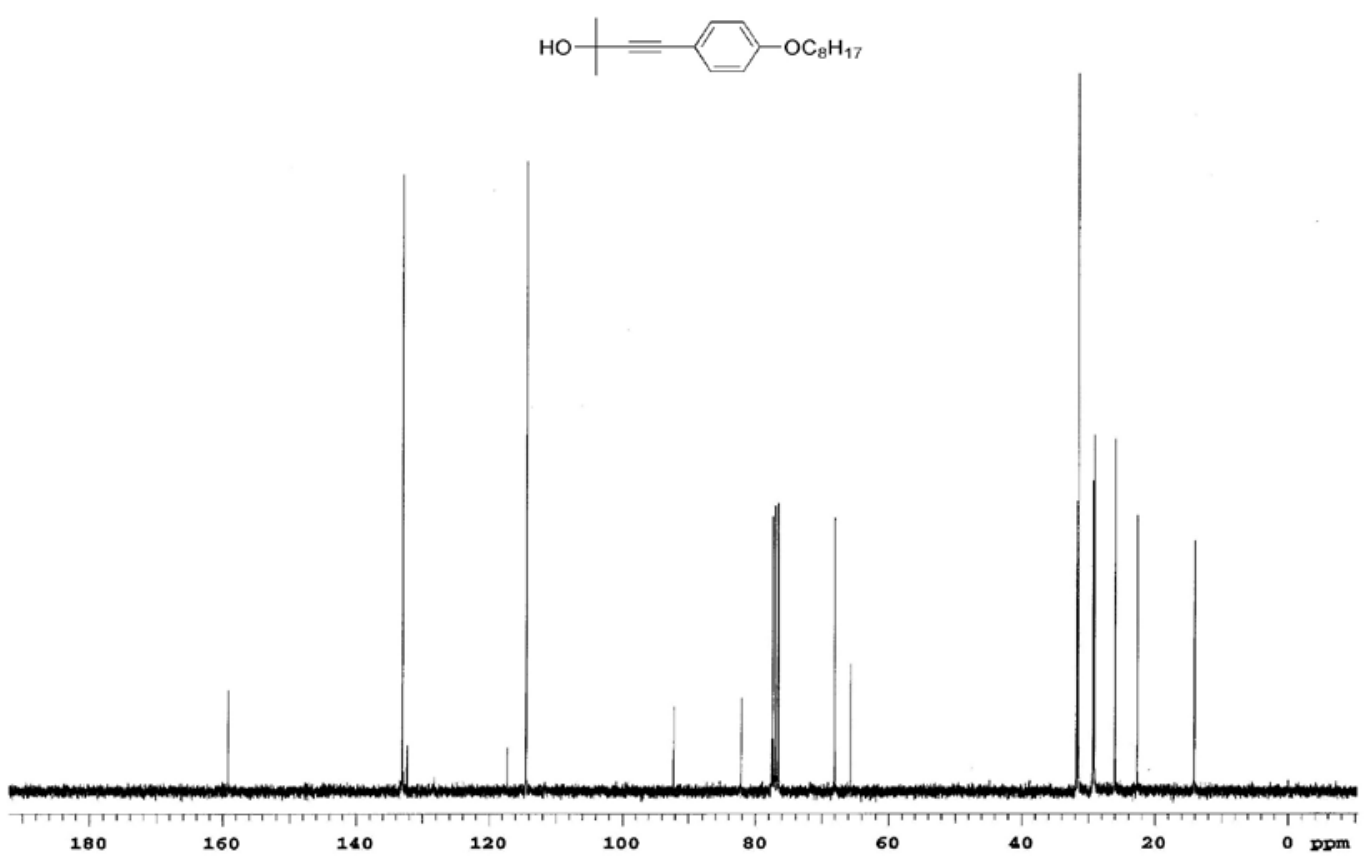

Figure S4. ${ }^{13} \mathrm{C}$ MRR spectrum of compound 4-(4-octyloxyphenyl)-2-methylbut-3-yn-2-ol (8) $\left(\mathrm{CDCl}_{3}, 75 \mathrm{MHz}\right)$.

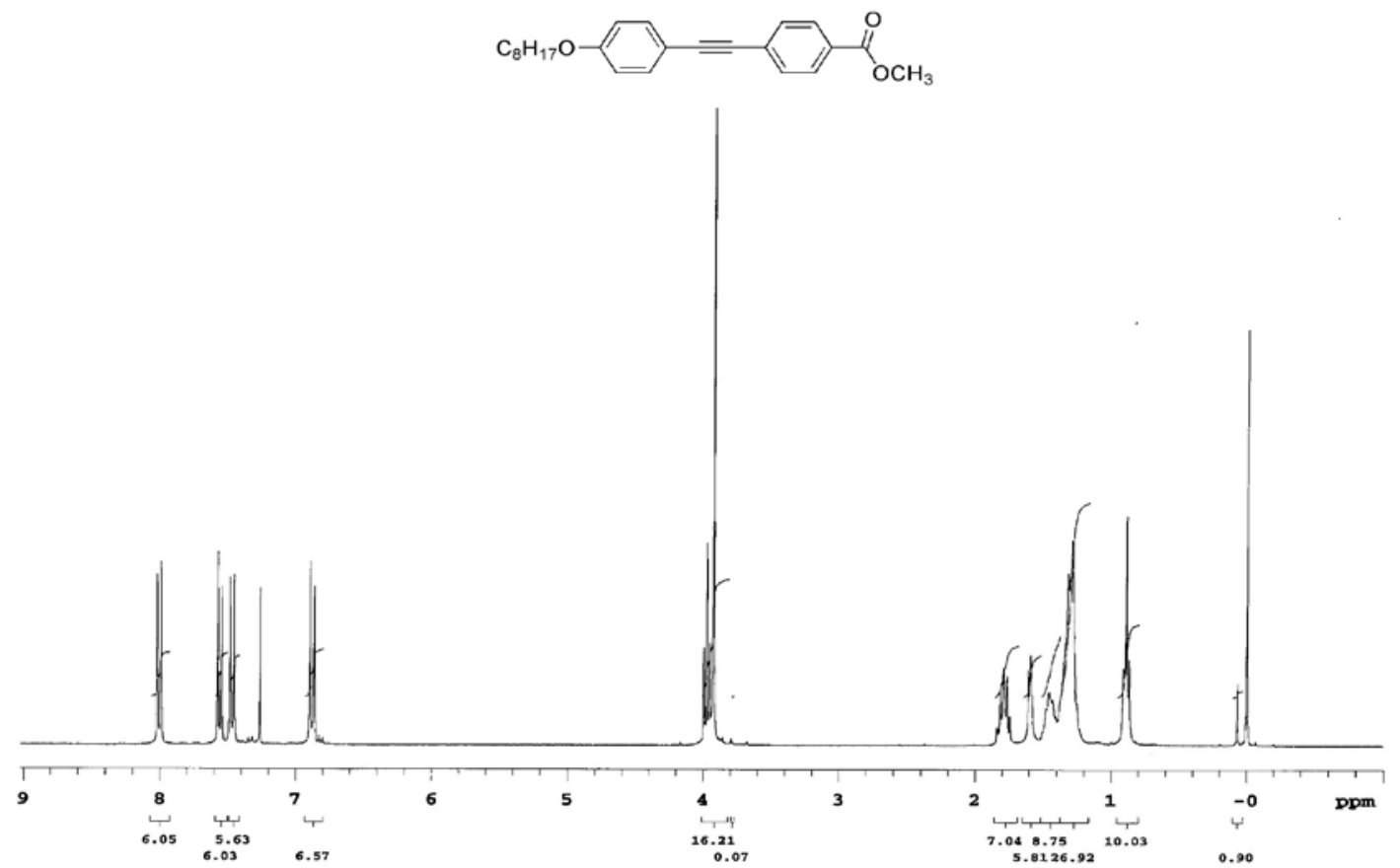

Figure S5. ${ }^{1} \mathrm{H}$ NMR spectrum of compound methyl-4-(4-octyloxyphenylethynyl)benzoate (9) $\left(\mathrm{CDCl}_{3}, 300 \mathrm{MHz}\right)$. 


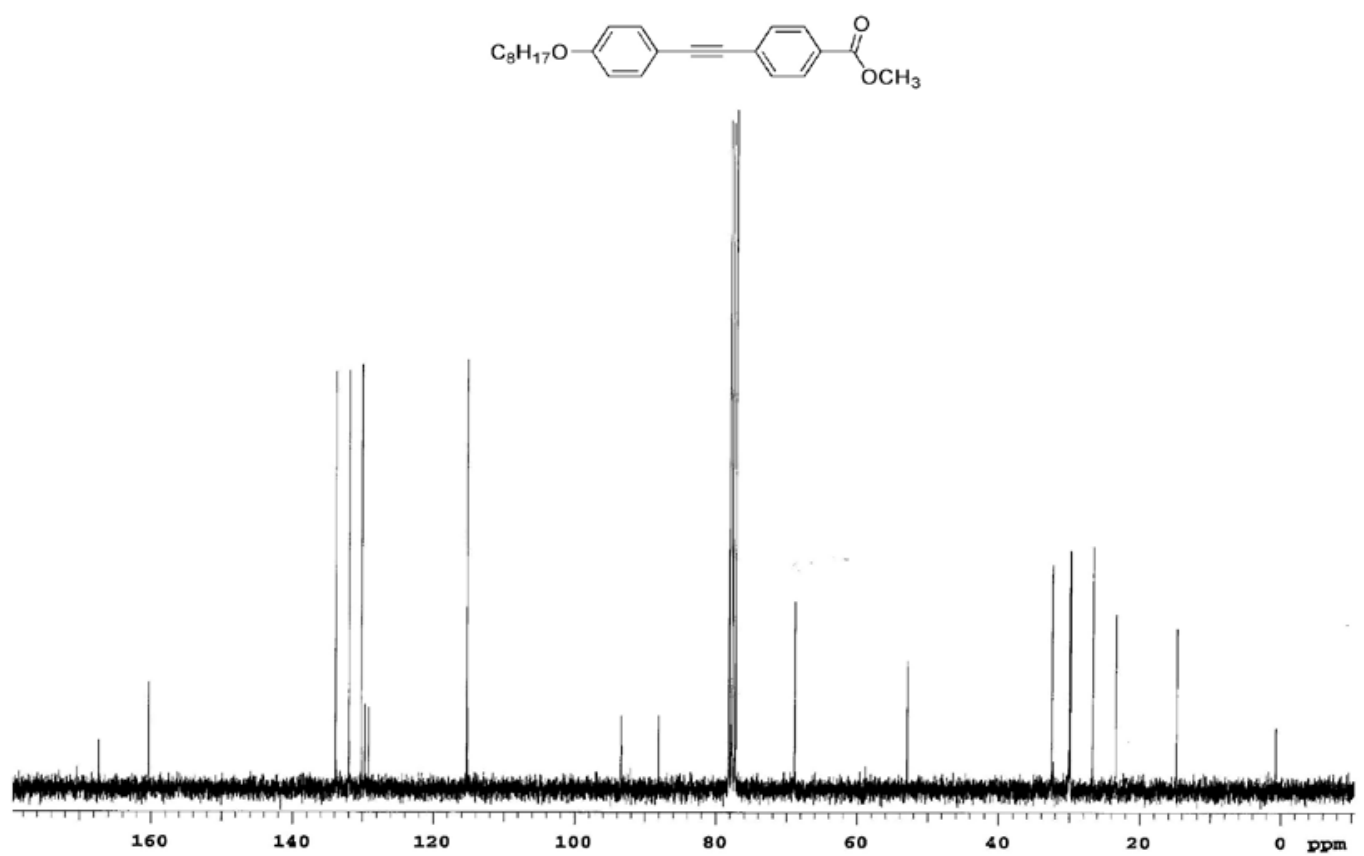

Figure S6. ${ }^{13} \mathrm{C}$ NMR spectrum of compound methyl-4-(4-octyloxyphenylethynyl)benzoate (9) $\left(\mathrm{CDCl}_{3}, 75 \mathrm{MHz}\right)$.

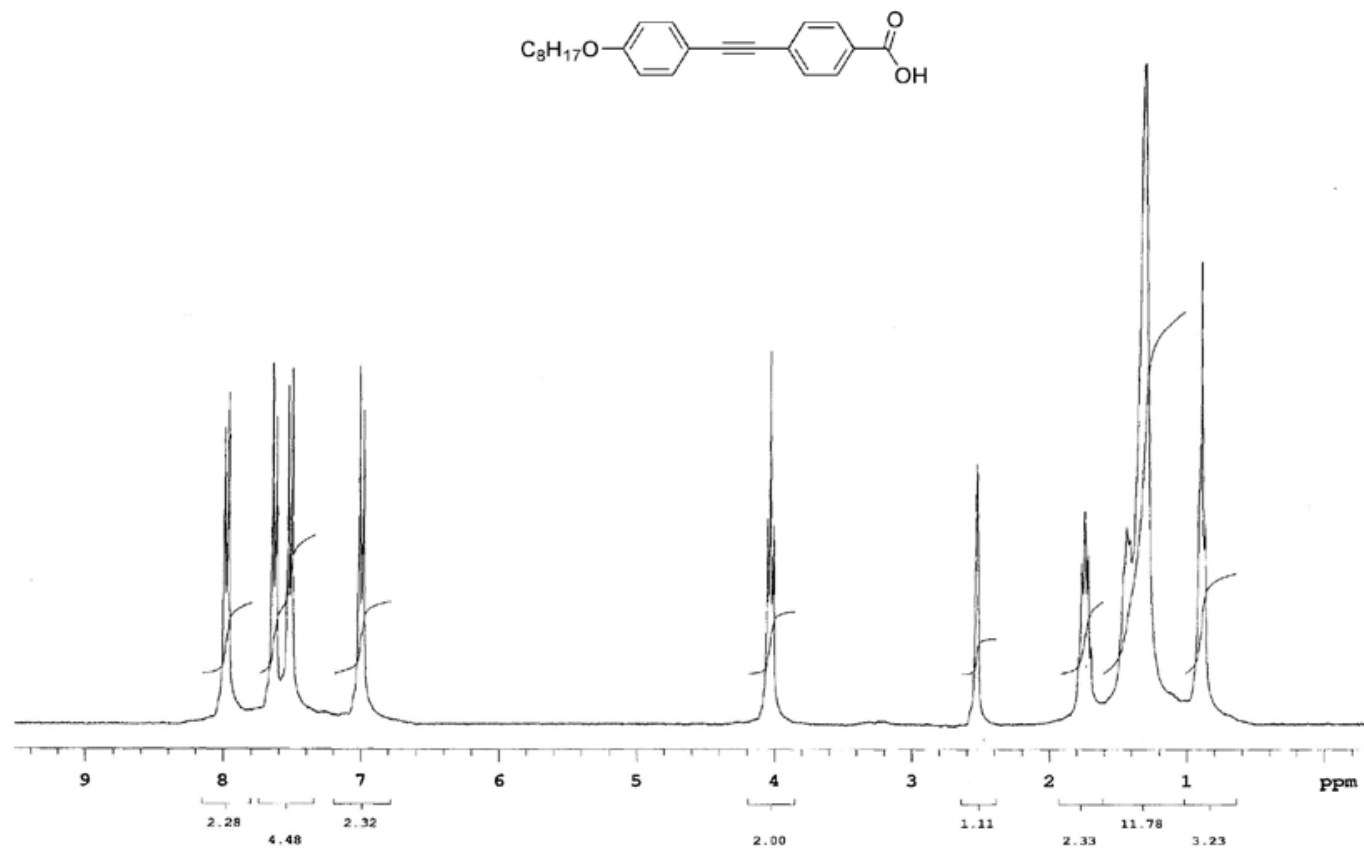

Figure S7. ${ }^{1} \mathrm{H}$ NMR spectrum of compound 4-[4-(octyloxyphenylethynyl)]benzoic acid (4) (DMSO- $d_{6}, 300 \mathrm{MHz}$ ). 

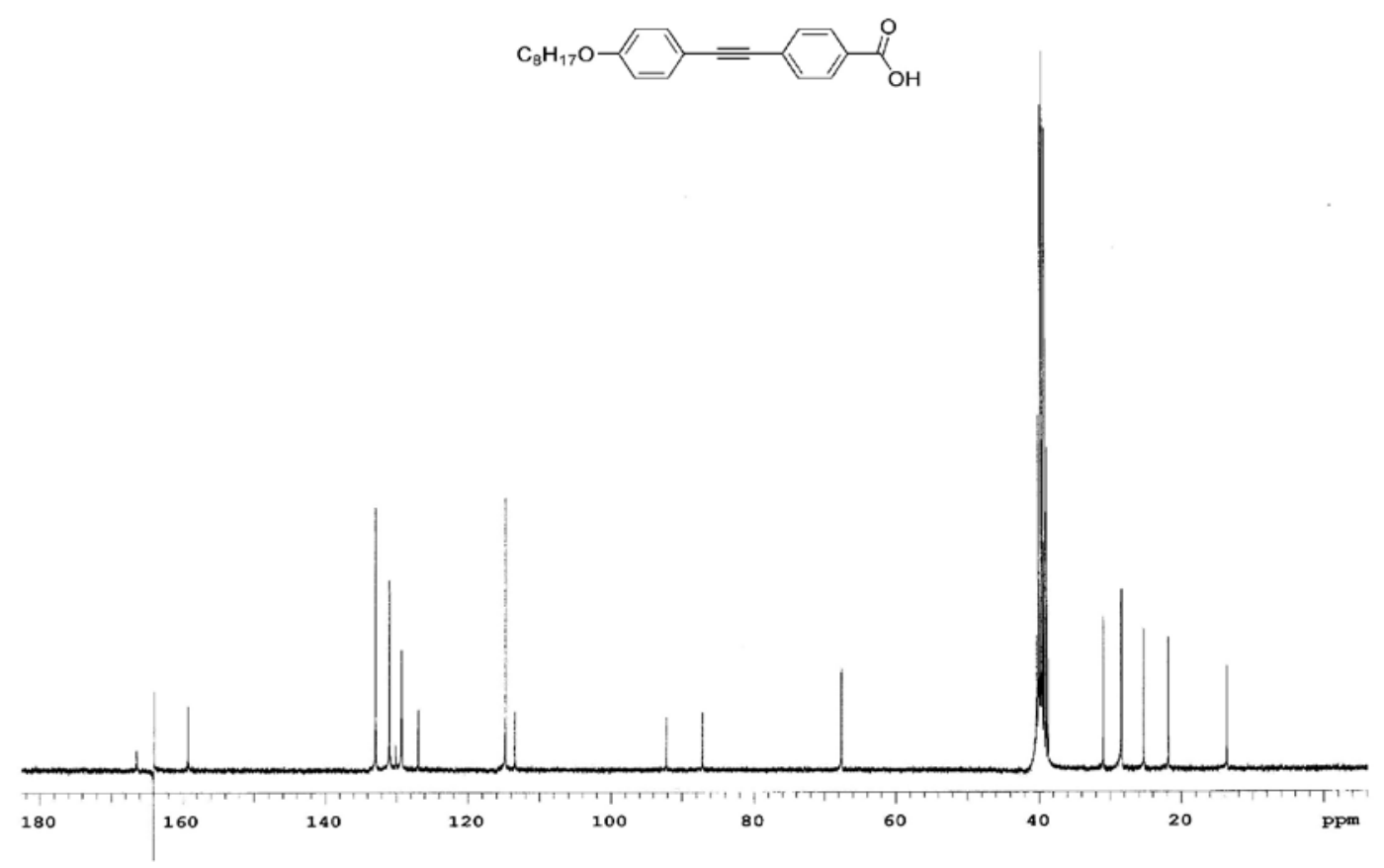

Figure S8. ${ }^{13} \mathrm{C}$ NMR spectrum of compound 4-[4-(octyloxyphenylethynyl)]benzoic acid (4) (DMSO- $d_{6}, 75 \mathrm{MHz}$ ).

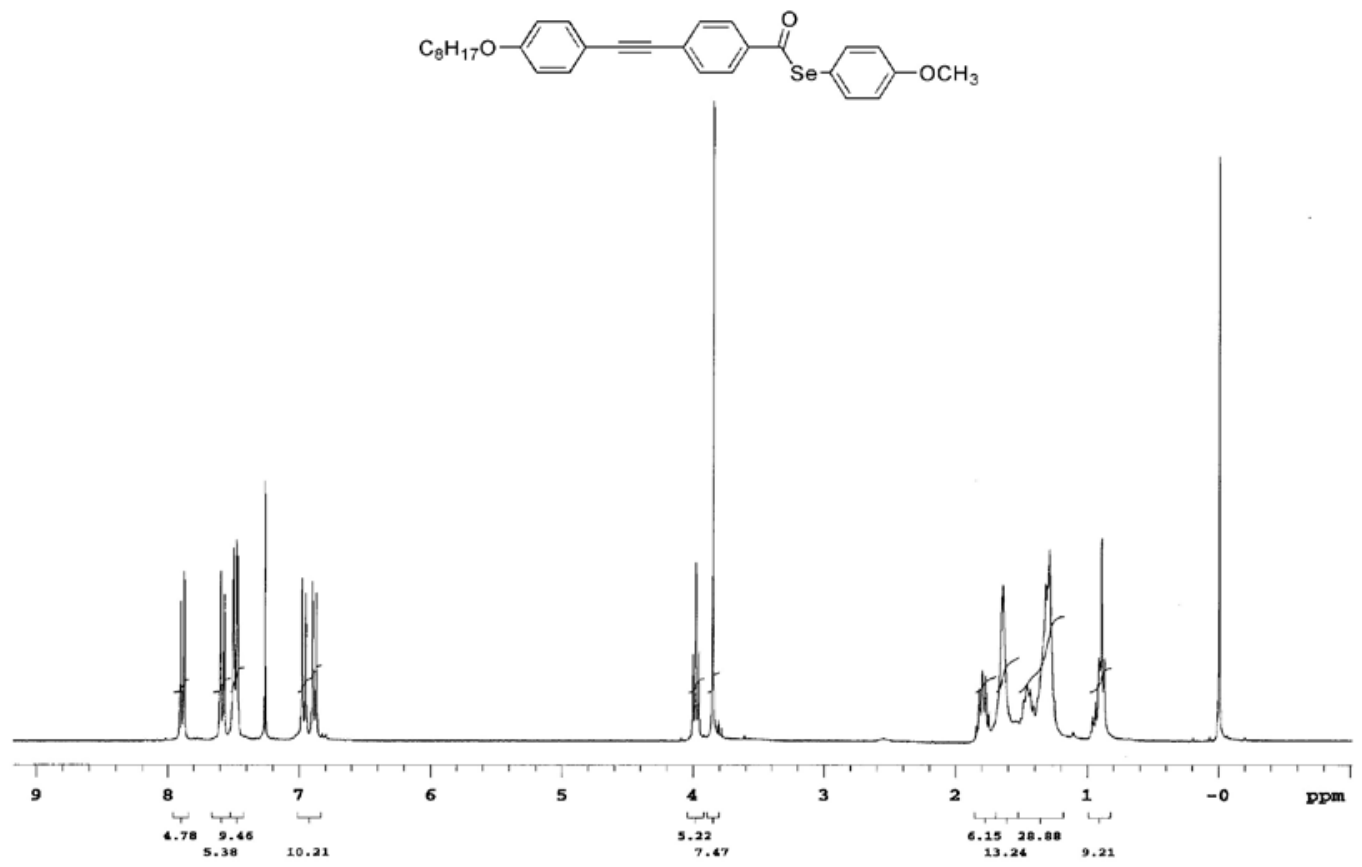

Figure S9. ${ }^{1} \mathrm{H}$ NMR spectrum of compound methoxyphenyl-4-[(4-octyloxyphenyl)ethynyl]-benzoselenoate (1a) $\left(\mathrm{CDCl}_{3}, 300 \mathrm{MHz}\right)$. 


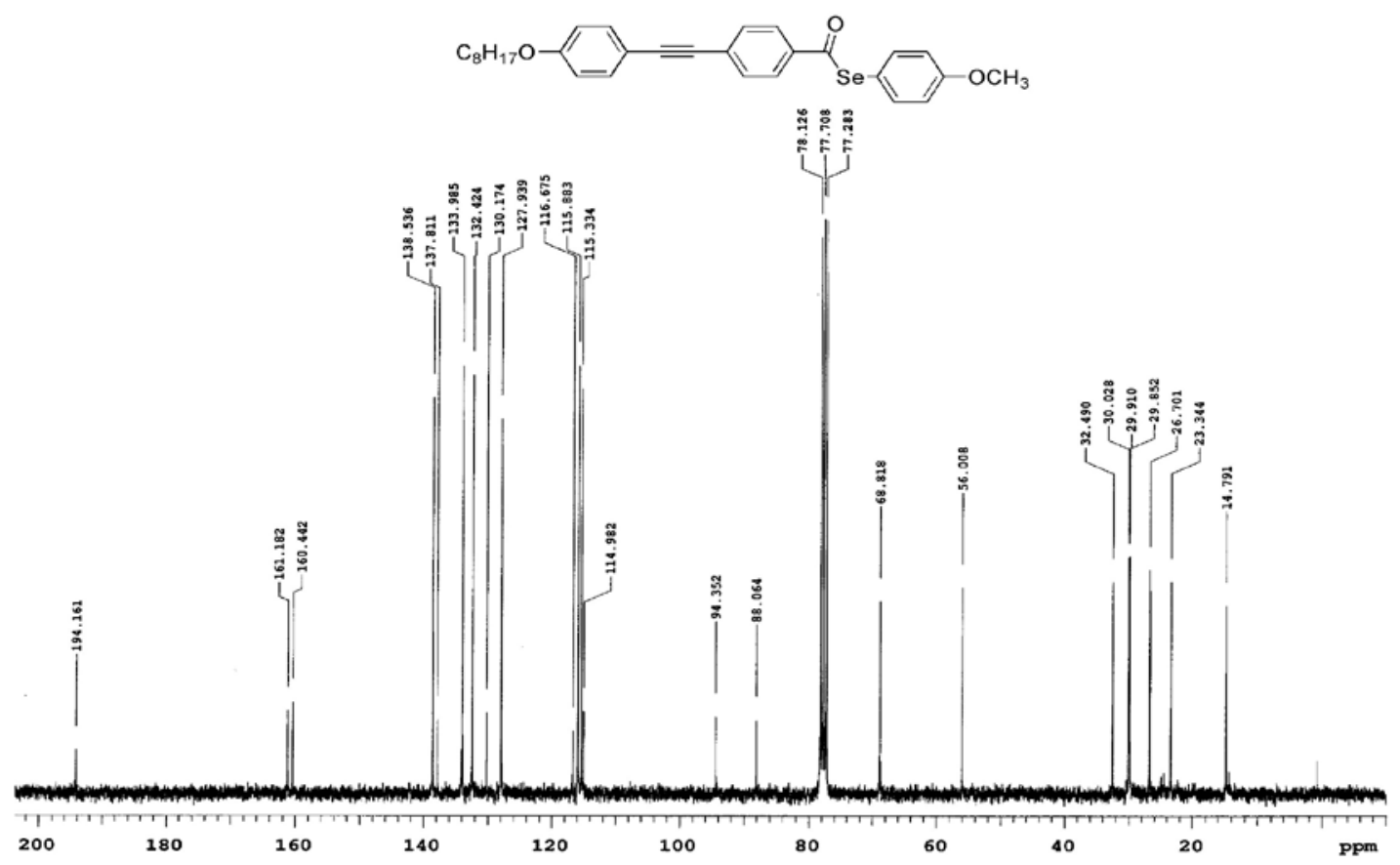

Figure S10. ${ }^{13} \mathrm{C}$ NMR spectrum of compound methoxyphenyl-4-[(4-octyloxyphenyl)ethynyl]-benzoselenoate (1a) $\left(\mathrm{CDCl}_{3}, 75 \mathrm{MHz}\right)$.

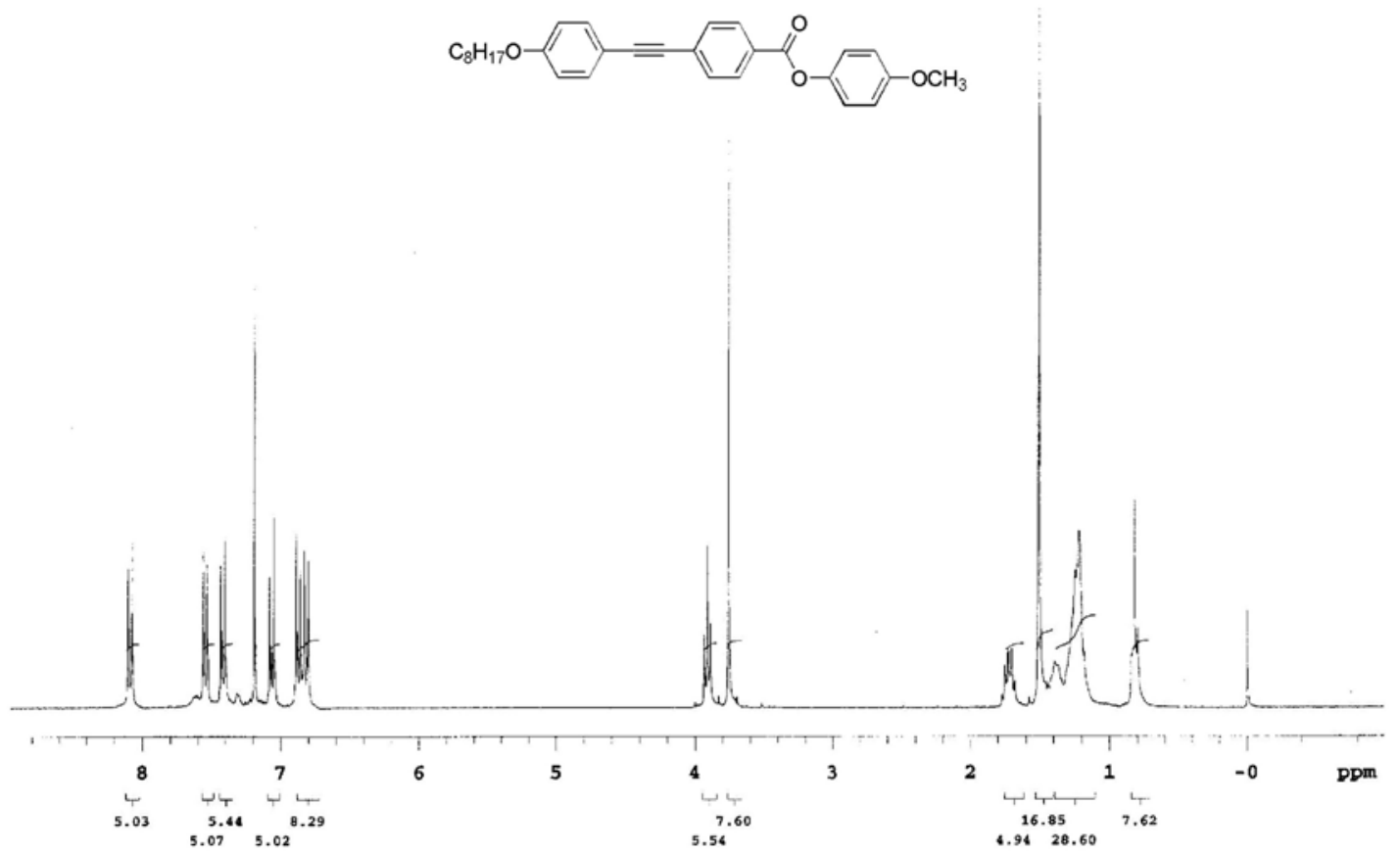

Figure S11. ${ }^{1} \mathrm{H}$ NMR spectrum of compound methoxyphenyl-4-[(4-octyloxyphenyl)ethynyl]-benzoate (6a) $\left(\mathrm{CDCl}_{3}, 300 \mathrm{MHz}\right)$. 

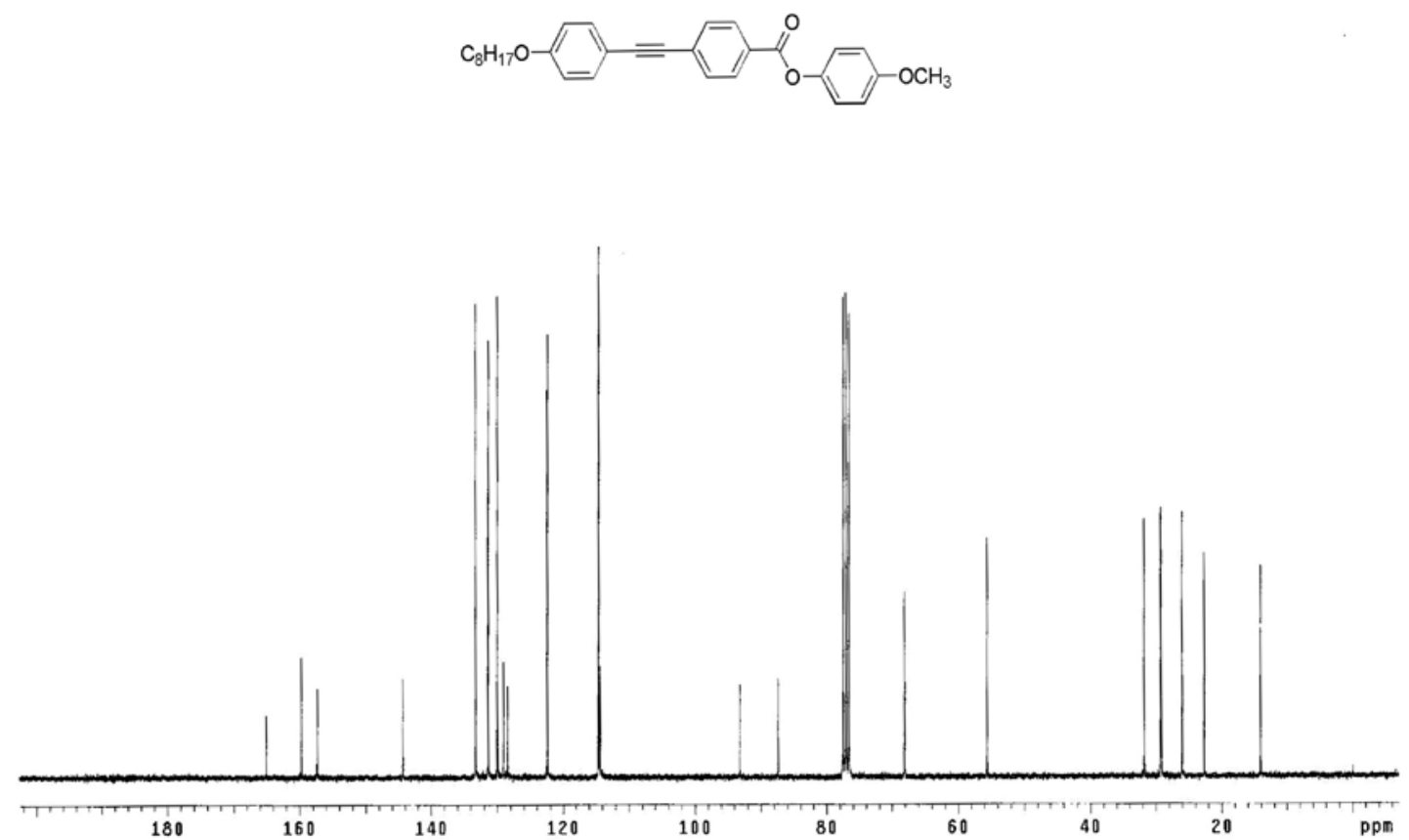

Figure S12. ${ }^{13} \mathrm{C}$ NMR spectrum of compound methoxyphenyl-4-[(4-octyloxyphenyl)ethynyl]-benzoate $(6 \mathbf{6 a})\left(\mathrm{CDCl}_{3}, 75 \mathrm{MHz}\right)$.

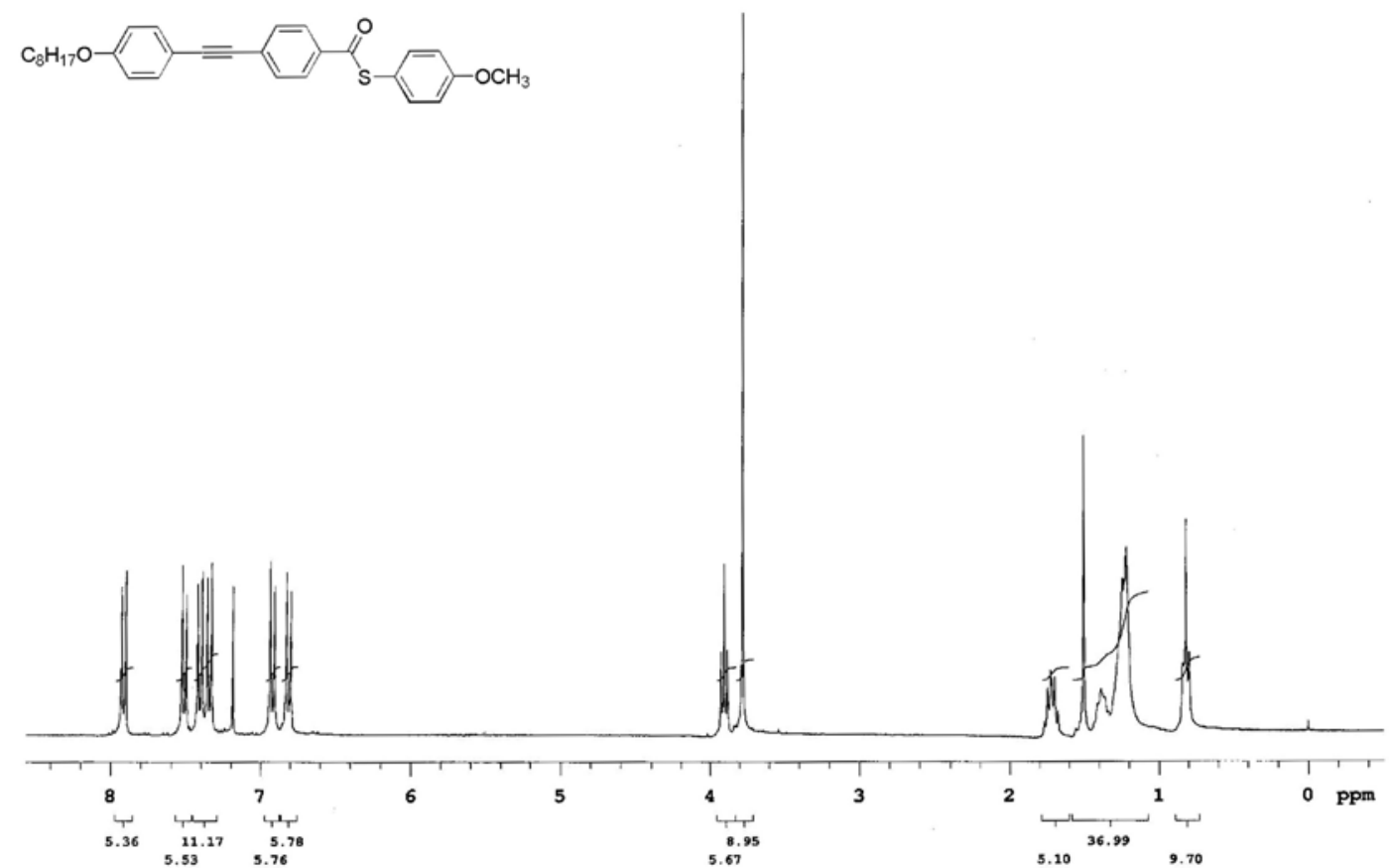

Figure S13. 'H NMR spectrum of compound methoxyphenyl-4-[(4-octyloxyphenyl)ethynyl]-benzothioate (6b) $\left(\mathrm{CDCl}_{3}, 300 \mathrm{MHz}\right)$. 

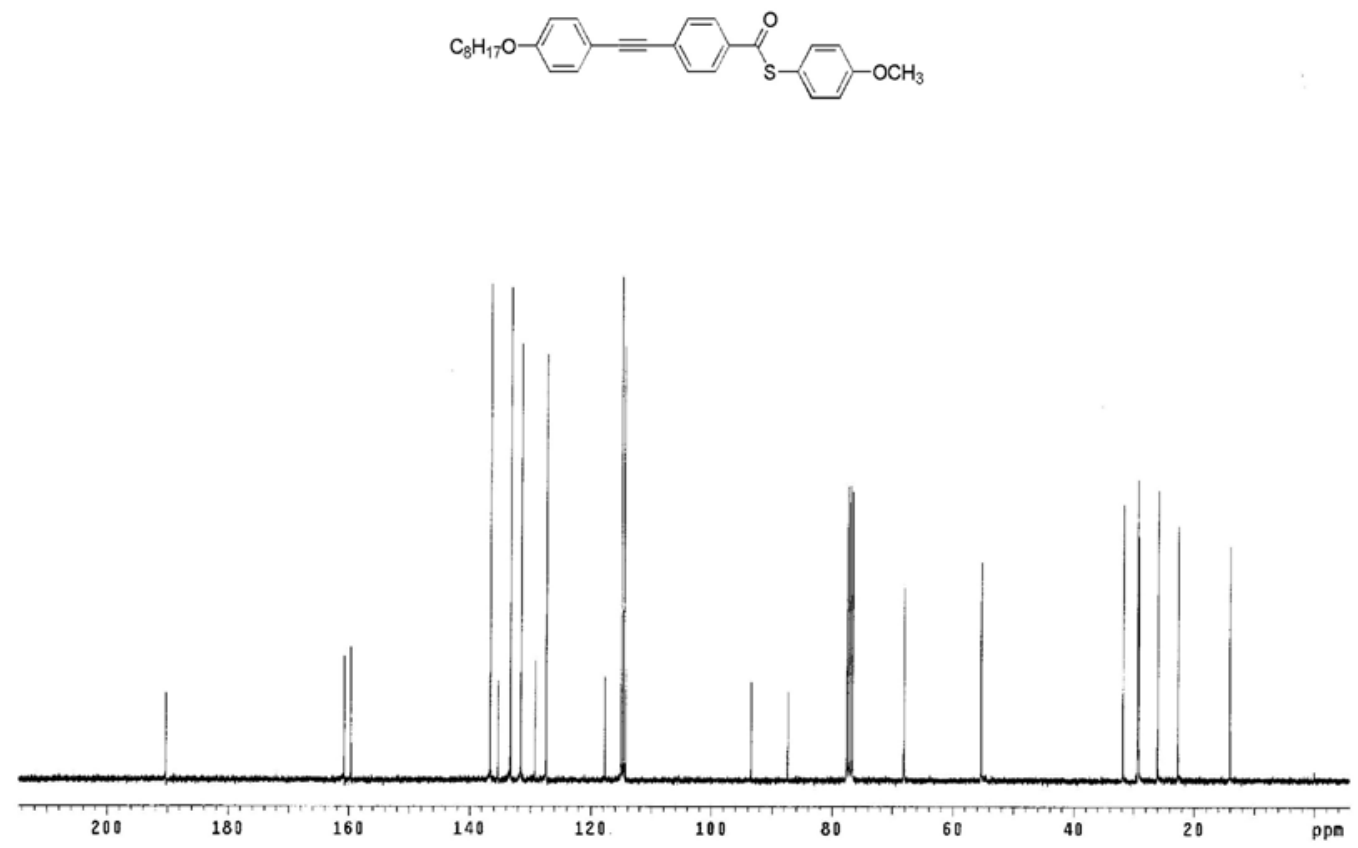

Figure S14. ${ }^{13} \mathrm{C}$ NMR spectrum of compound methoxyphenyl-4-[(4-octyloxyphenyl)ethynyl]-benzothioate $(6 \mathbf{b})\left(\mathrm{CDCl}_{3}, 75 \mathrm{MHz}\right)$.

Infrared spectra of compounds

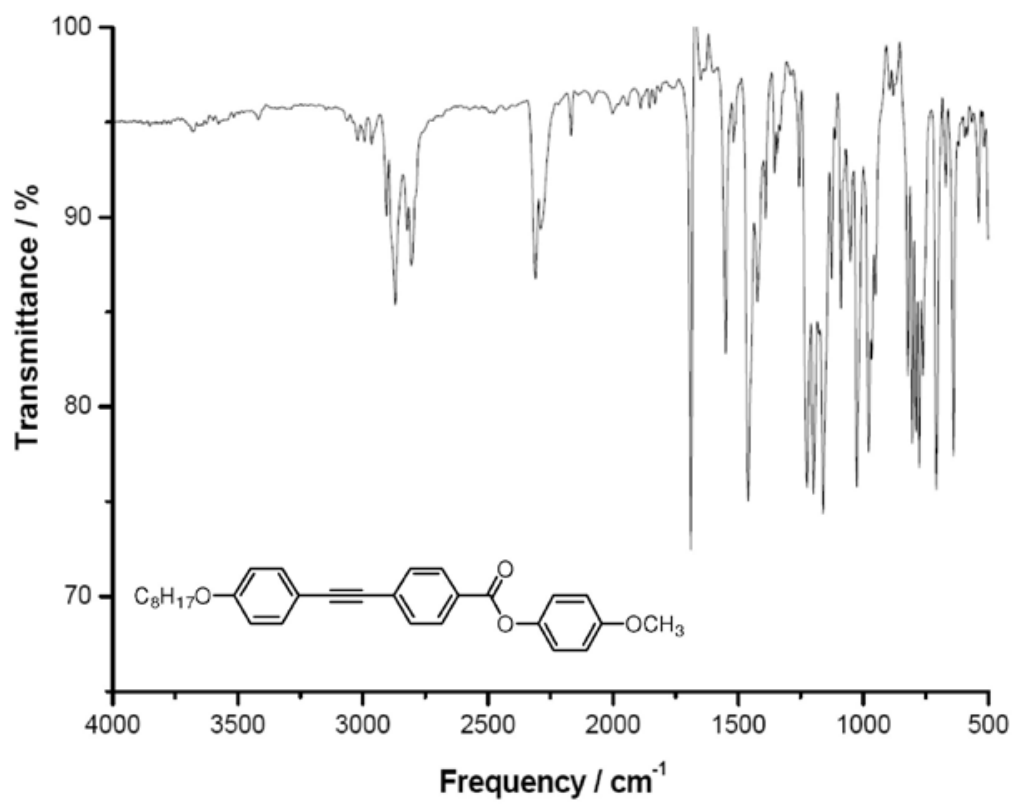

Figure S15. Infrared spectrum of compound methoxyphenyl-4-[(4-octyloxyphenyl)ethynyl]-benzoate (6a). 


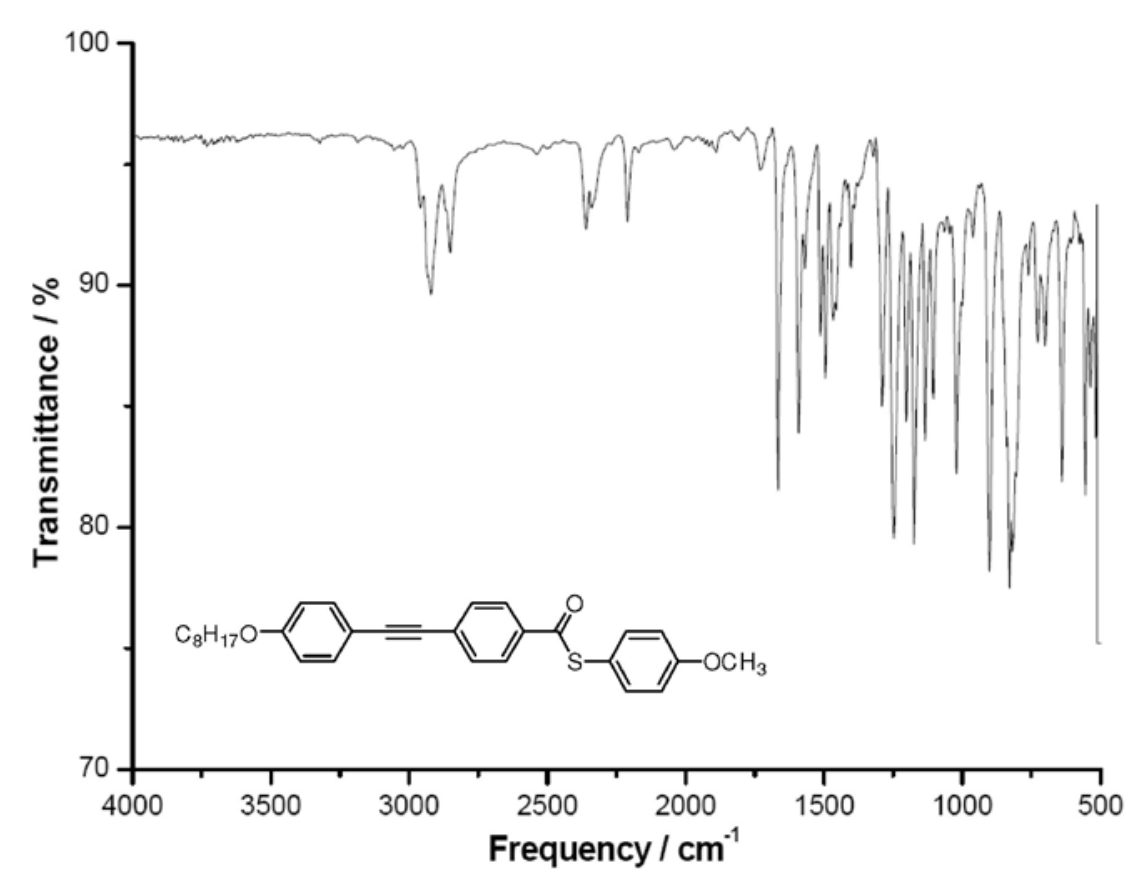

Figure S16. Infrared spectrum of compound methoxyphenyl-4-[(4-octyloxyphenyl)ethynyl]-benzothioate (6b).

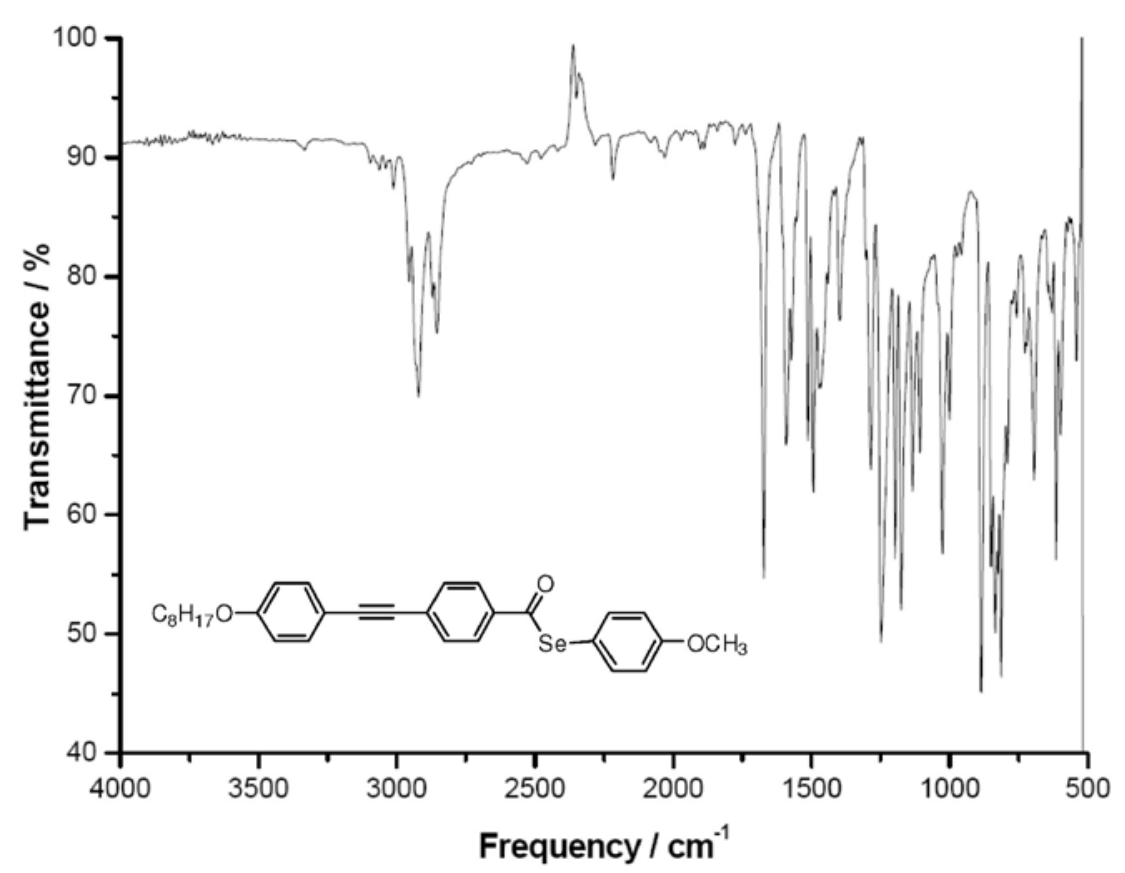

Figure S17. Infrared spectrum of compound methoxyphenyl-4-[(4-octyloxyphenyl)ethynyl]-benzoselenoate (1a). 


\section{$U V$-Vis absorption spectra of compounds}

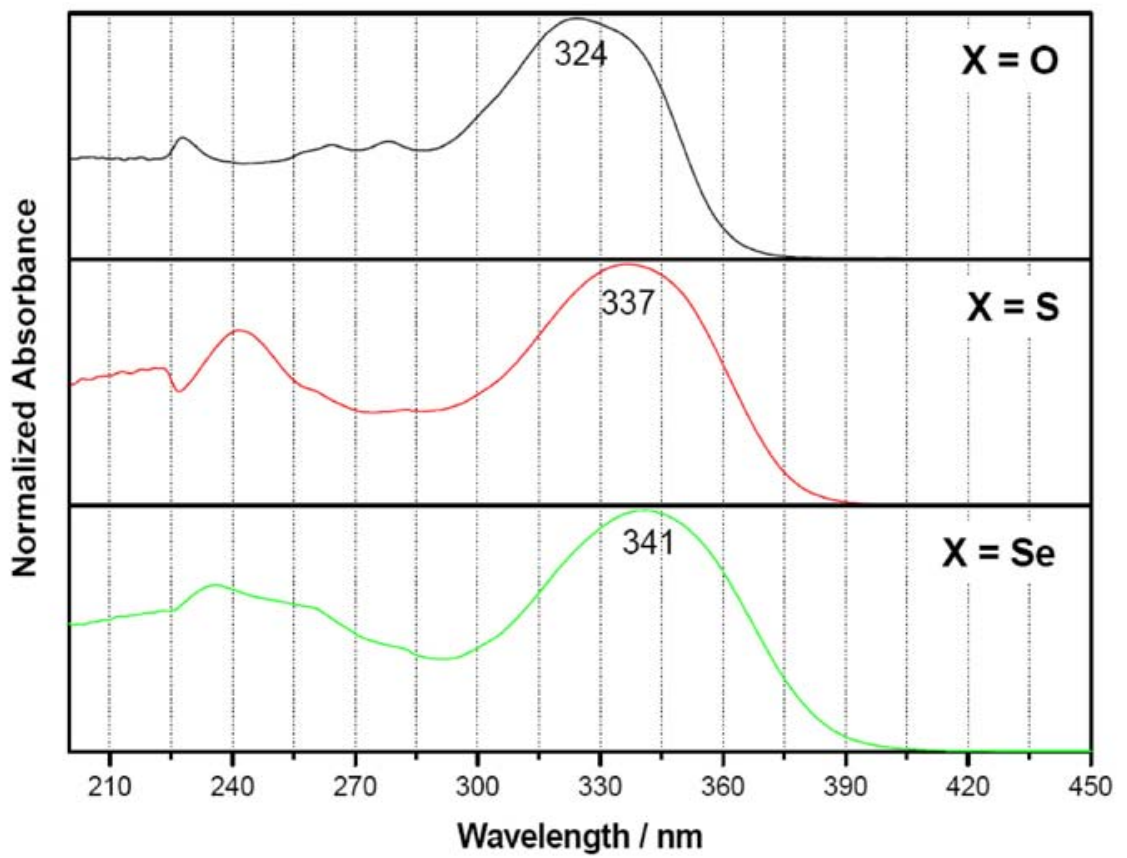

Figure S18. Normalized absorption spectra of the dyes $6 \mathbf{6}, \mathbf{6 b}$ and $1 \mathbf{a}$, where $X=\mathrm{O}, \mathrm{S}$ and Se, respectively.

\section{DSC thermograms}

Thermograms set for compounds $\mathbf{6 a}, \mathbf{6} \mathbf{b}$ and $\mathbf{1 a}$ on heating at $10^{\circ} \mathrm{C} \mathrm{min}^{-1}$.

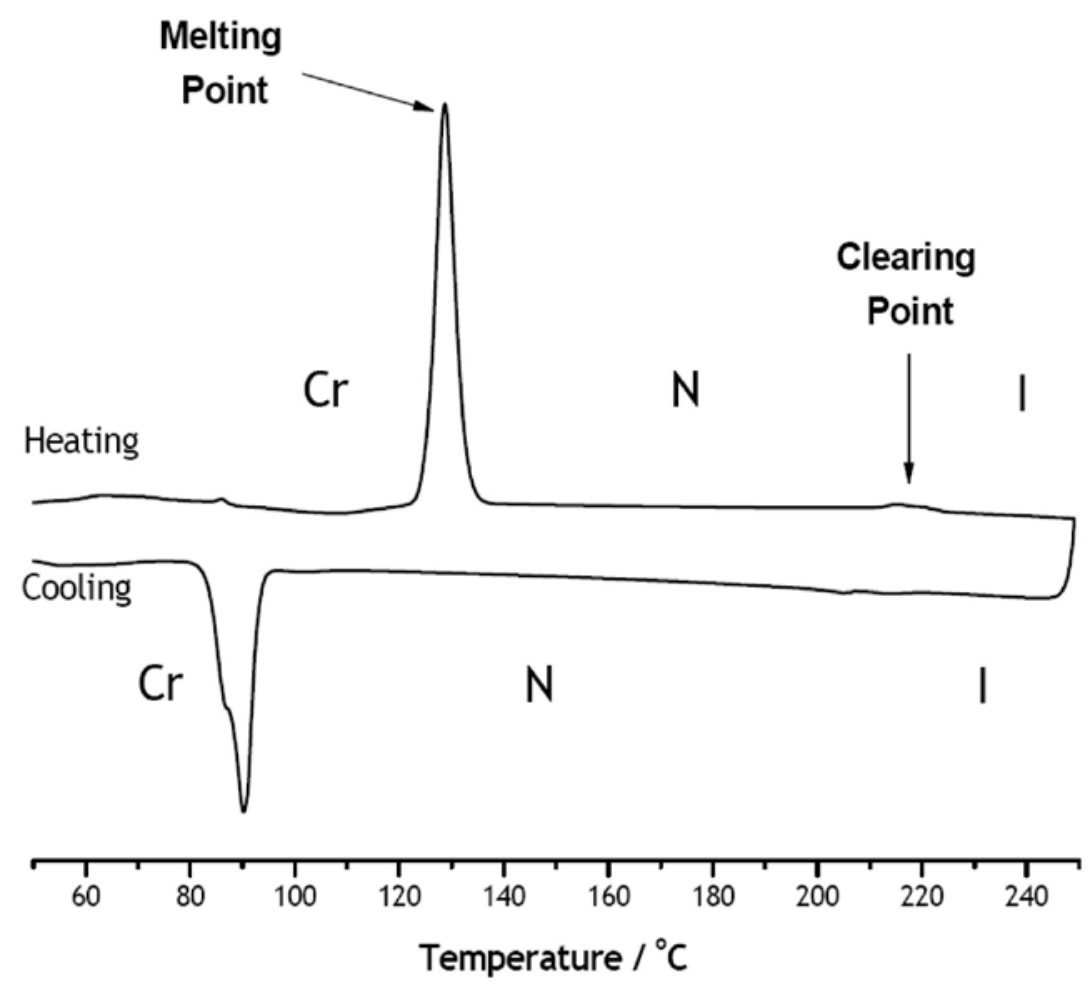

Figure S19. Thermogram for compound methoxyphenyl-4-[(4-octyloxyphenyl)ethynyl]-benzoate (6a). 


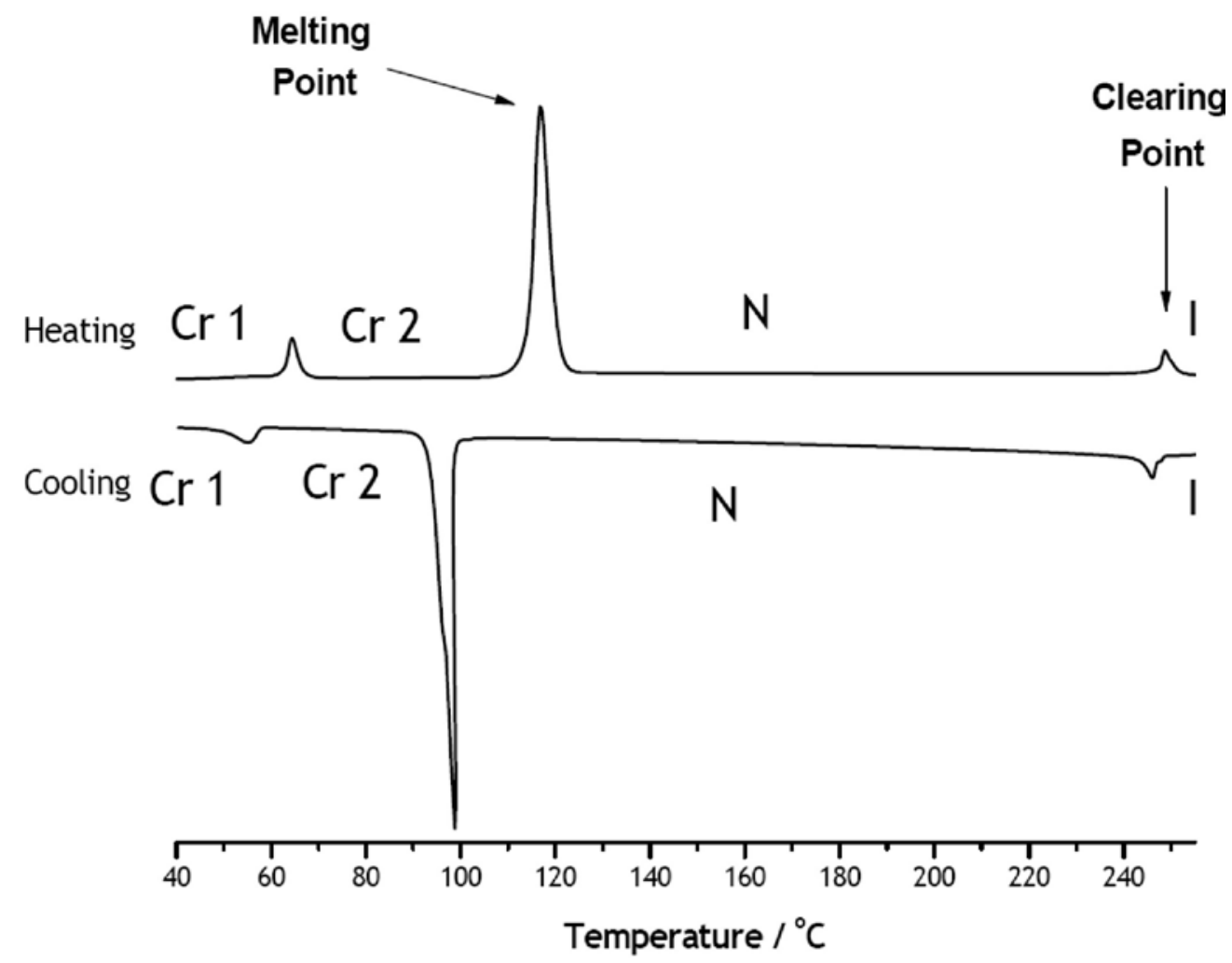

Figure S20. Thermogram for compound methoxyphenyl-4-[(4-octyloxyphenyl)ethynyl]-benzothioate (6b).

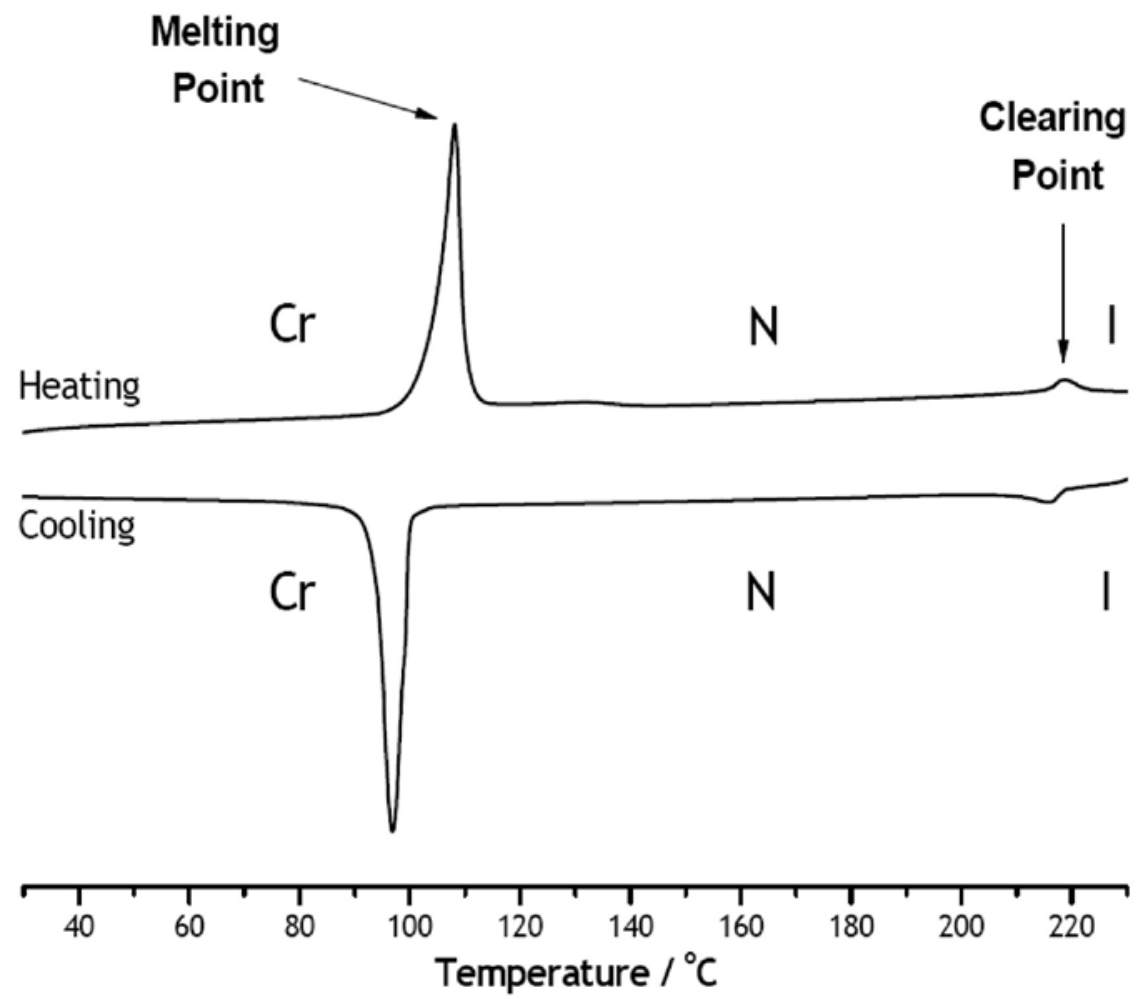

Figure S21. Thermogram for compound methoxyphenyl-4-[(4-octyloxyphenyl)ethynyl]-benzoselenoate (1a). 


\section{Microscopic analysis}

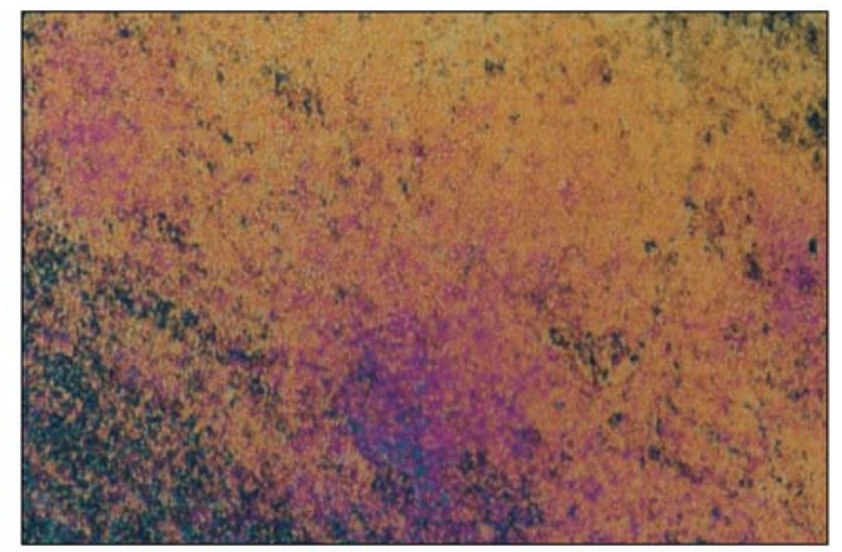

Figure S22. Schlieren texture grainy of methoxyphenyl-4-[(4-octyloxyphenyl)ethynyl]-benzoate (6a) occurring at $150{ }^{\circ} \mathrm{C}$.

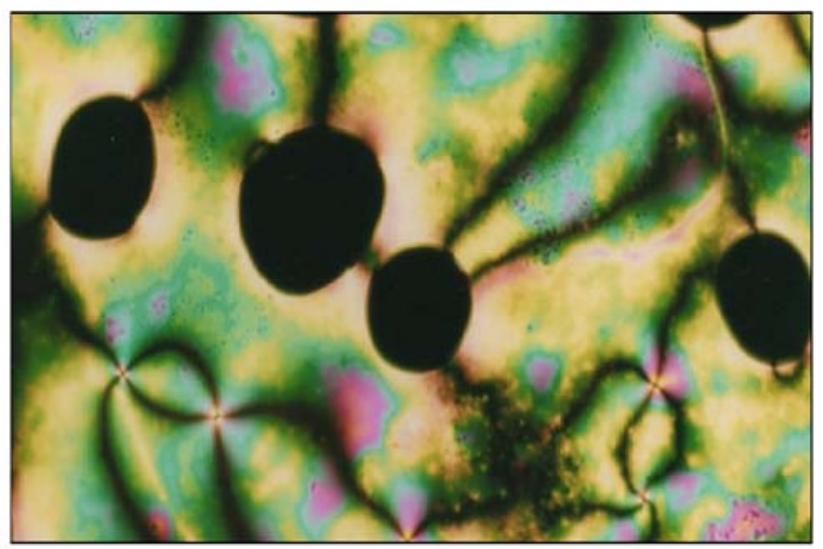

Figure S23. Planar thread-like nematic texture of methoxyphenyl-4-[(4-octyloxyphenyl)ethynyl]-benzothioate (6b) occurring at $220^{\circ} \mathrm{C}$.

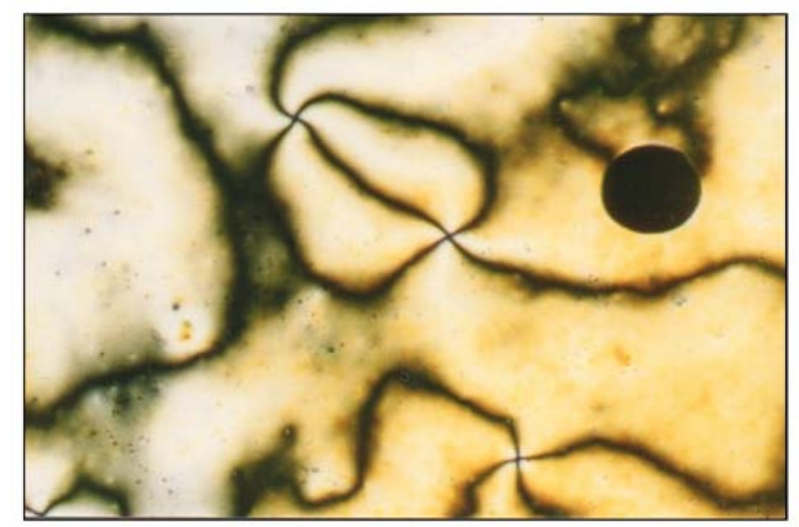

Figure S24. Planar thread-like nematic texture of methoxyphenyl-4-[(4-octyloxyphenyl)ethynyl]-benzoselenoate (1a) occurring at $174{ }^{\circ} \mathrm{C}$. 